Portland State University

PDXScholar

$1-10-1998$

\title{
Morphology, Eruption Rates, and Rheology of Lava Domes: Insights from Laboratory Models
}

Jonathan H. Fink

Portland State University, jon.fink@pdx.edu

Ross W. Griffiths

Arizona State University

Follow this and additional works at: https://pdxscholar.library.pdx.edu/geology_fac

Part of the Geology Commons, and the Volcanology Commons

Let us know how access to this document benefits you.

\section{Citation Details}

Fink, J. H., \& Griffiths, R. W. (1998). Morphology, eruption rates, and rheology of lava domes: Insights from laboratory models. Journal of Geophysical Research: Solid Earth (1978-2012), 103(B1), 527-545.

This Article is brought to you for free and open access. It has been accepted for inclusion in Geology Faculty Publications and Presentations by an authorized administrator of PDXScholar. Please contact us if we can make this document more accessible: pdxscholar@pdx.edu. 


\title{
Morphology, eruption rates, and rheology of lava domes: Insights from laboratory models
}

\author{
Jonathan H. Fink \\ Department of Geology, Arizona State University, Tempe \\ Ross W. Griffiths \\ Research School of Earth Sciences, The Australian National University, Canberra
}

\begin{abstract}
The growth of lava domes can be either quiescent or violent, with transitions between styles of behavior commonly occurring with little waming. Here we propose that the behavior depends on the eruption rate, the magma rheology, and the thickness of the cooling surface. We present a model, based on laboratory simulations, field measurements, and photographic analysis, that relates the morphology and texture of a dome to the thickness of its cooled carapace, and thence to eruption conditions. A sequence of four main types of dome (spiny, lobate, platy, and axisymmetric) is identified in laboratory analog experiments with a Bingham plastic. These regimes are associated with progressively higher effusion rates, lower cooling rates, lower yield strengths, and (in real lava flows) decreasing tendency for explosive decompression during flow front collapse and are ordered according to the value of a single dimensionless number. The model allows an estimate of the yield strengths of the magma forming active domes based on data for the effusion rate and composition. It also permits the eruption rates of prehistoric or extraterrestrial lava domes and flows to be appraised from their morphology, if their compositions can be estimated. A comparison with the laboratory results suggests that the Venusian "pancake domes" are likely to have basaltic to basaltic andesitic composition.
\end{abstract}

\section{Introduction}

Although most geologists may not be aware of it, the late twentieth century could be considered the golden age for the study of lava domes. These often neglected masses of volcanic rock, which emerge as precursors or postscripts to many of the largest explosive eruptions, have recently gained notoriety on several fronts. Of 15 "Decade Volcanoes" selected for detailed study as part of the International Decade of Natural Disaster Reduction [Newhall, 1994], at least five (Colima, Mexico; Santa Maria, Guatemala; Galeras, Colombia; Unzen, Japan; Merapi, Indonesia) have recent activity dominated by the growth of lava domes. The limits of our understanding of domes have been highlighted by sudden and deadly collapses of those at Unzen, Merapi, and Santa Maria, resulting in pyroclastic flows and surges that caused scores of fatalities (including three volcanologists). Concerns about such hazards have also led to the present evacuation of parts of the island of Montserrat. Similarly, explosive disruption of the lava dome at Galeras in 1993 killed six volcanologists and injured three others. Also enigmatic has been the discovery of dozens of large, highly circular domes on the planet Venus, whose compositions remain a mystery. On the other hand, precise monitoring of the growth of domes at Mount St. Helens in Washington and Soufrière of St. Vincent in the Caribbean has

Copyright 1998 by the American Geophysical Union.

Paper number 97JB02838.

$0148-0227 / 98 / 97 \mathrm{JB}-02838 \$ 09.00$ provided unprecedented opportunities for developing increasingly accurate models relating the extrusion of silicic magmas to their cooling, solidification, and rheology.

Despite this increased attention, several outstanding questions about lava domes persist. Some of these extrusions seem more susceptible than others to explosive decompression and pyroclastic flow generation. Are there early indicators that a particular dome has (or is developing) such violent potential? Does the overall shape or surface texture of a dome reflect factors that also influence its ability to retain volatile pressure, or is underlying topography the only important variable? What are the most important factors determining the style of eruption? Actual measurements of the eruption rates of lava domes are rare, making it difficult to predict the areas likely to be covered by flows, or how long it will take for them to be affected. If it were possible to relate the effusion rates of domes to their morphology and structure, we could estimate how long it took for dozens of prehistoric flows to be emplaced and, using this information, better understand the mechanics and range of behaviors of active lava domes.

To address these questions, we combine three sources of information: analog modeling using materials that mimic many of the morphologic and textural properties of natural domes; field measurements and observations of active extrusions at Mount St. Helens, Soufrière, Unzen, Santa Maria, Merapi, Pinatubo (Philippines), Redoubt (Alaska), and Montserrat; and photogeologic observations of earlier Holocene and Recent domes. The experiments use a new method of simulation in which a temperature-dependent Bingham-plastic slurry is injected at controlled rates into tanks of cold water. Analysis of the labo- 
ratory results suggests that transitions between four principal dome types depend on the dimensionless ratio of slurry solidification rate to eruption rate. An assumption of dynamic similarity lets us apply these results to measurements of active domes, leading to semiempirical but quantitative interpretations of the morphology and texture of natural extrusions. This approach leads to a general physical framework within which specific domes can be placed. It may also allow us: (1) to infer the eruption rates of prehistoric domes from their surface appearance and known composition, (2) to assess the maximum pressure that can be retained beneath the cooled carapace of an actively growing dome, and (3) to use the shapes of the socalled "pancake domes" on Venus to estimate their compositions.

\section{Laboratory Simulations of Lava Domes}

During most dome eruptions, accurate measurements of effusion rates, lava temperatures, and rheologic properties can only be obtained sporadically, if at all. Thus developing a comprehensive model that relates morphology to eruption conditions solely on the basis of observations of active domes is not practical. As an alternative, we and others have turned to laboratory analogs to better parameterize the growth of lava domes. Previous laboratory-based models of lava flow emplacement have shown that both their morphology and dynamics are controlled by the ratio of eruption rate to cooling rate [e.g., Fink and Griffiths, 1990; Griffiths and Fink, 1993]. Here we will review the hypothesis that the same variables play a dominant role in the development of lava domes, which occupy the high-strength, high-viscosity, more silicic, and more crystal-rich end of the lava flow spectrum.

\subsection{Analog Materials}

Several different substances have been used by previous workers to simulate lava flow processes. In order to reproduce the physics controlling the morphologic evolution of domes, we need a material whose rheology incorporates temperature dependence and a finite yield strength. The yield strength is required if we are to capture the effects on lava flows of magma crystal contents of up to $60 \%$ by volume, as it erupts from a vent. Polyethylene glycol wax (PEG) has a Newtonian viscosity when molten and the ability to deform in either a ductile or brittle manner (depending on temperature and the level of applied stress) when solid. For these reasons it has been used in many lava flow simulation studies, extruded either in air [e.g., Hodgson, 1969; Greeley and Womer, 1981; Park and Iversen, 1984] or under water [e.g., Hallworth et al., 1987; Fink and Griffiths, 1990, 1992; Griffiths and Fink, 1993; Gregg and Fink, 1995]. The main limitation of PEG is that unlike magnas with large crystal or bubble contents, it lacks a finite yield strength at temperatures above its freezing point so that model domes cannot sustain large shear stresses in their liquid interiors. This behavior also reduces PEG's capacity to replicate fracture processes. Kaolin slurries do possess such strength if sufficiently concentrated in the solid component, making them potentially attractive analog materials [e.g., Hulme, 1974; Blake, 1990]. However, solidification of kaolin/water suspensions by cooling the surface of a flow would be difficult to achieve in practical laboratory experiments, so they cannot be used to evaluate the role of a cooling crust.
In our attempts to simulate dome growth we have combined the advantages of both of the above systems, preparing slurries of kaolin powder suspended in liquid PEG. The resulting mixtures have a finite strength at room temperature as well as plastic viscosities and yield strengths that increase upon cooling. When injected into a tank of cold water (which provides for rapid heat loss and removes surface tension), this analog can reproduce the overall morphologic features of natural lava domes, as well as some of the finer scale textural aspects. Video recordings let us evaluate not only the final shape and structure of simulated extrusions but also their temporal evolution. We conducted 20 runs in which nearly identical batches of slurry were pumped at differing rates through a $2 \mathrm{~cm}$ diameter hole in the flat base of a $30 \mathrm{~cm}$ square tank of water whose temperature could also be varied. The experiments and results are reported in detail elsewhere [Griffiths and Fink, 1997]. However, we briefly summarize them in this section and report additional observations relevant to our present purpose. We include photographs and cross sections of several experiments showing the effects of changing eruption rate, eruption history, and cooling rate. These results, when appropriately scaled, can assist in the quantitative interpretation of natural dome morphology.

\subsection{Simulation Results}

Figures 1 and 2 show top and side views, respectively, of the final stages of four of our kaolin slurry runs. The progressions from Figures 1a through 1d and 2a through $2 \mathrm{~d}$ are typical of sequences corresponding to decreasing cooling rates achieved by increasing either the eruption rate, water temperature, or slurry temperature. All of the photographs show cases in which the slurry was extruded onto a horizontal surface of smooth Plexiglas. At late stages of some experiments, especially those with higher ambient temperatures, the water became cloudy because some clay particles came out of suspension as small amounts of PEG dissolved. Although not shown in Figures 1 and 2, at the conclusion of many experiments we dissected the domes to measure the thickness of the solidified surface crust.

Figures 1a and 2a show a run in which the effusion rate and water temperature were both low. As a result, the dome did not develop a prominent central portion with a persistent molten core. Rather, a series of angular, spine-like lobes extruded steeply upward out of the vent and then laid over, piling on top of each other. These elongate, exogenous lobes had relatively smooth surfaces ribbed by grooves that parallel the extrusion direction. The overall structure had a highly irregular planform and cross-sectional shape because it was made up of the accumulation of nearly a dozen distinct lobes and spines. However, because the dimensions of these lobes and the positions of active fracture surfaces did not change appreciably during the course of an experiment, and because the strong crust on each extrusion did not undergo extension, the surface texture retained a smooth appearance. We refer to this type of dome as spiny. In runs with even lower water temperatures, a narrow, noodle-like tube of slurry oozed from the vent like toothpaste (or an upheaved plug [Williams, 1932]), folding upon itself to form a structure that bore little resemblance to any natural lava formations.

Warmer bath temperatures and/or faster effusion rates produced domes in which radial lobes were fewer in number, were broader in width, and were emplaced in a more lateral fashion. For much of their growth these domes consisted of four to six 
$\mathbf{a}$

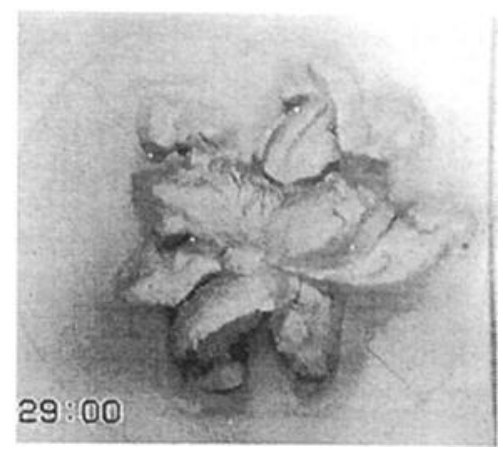

c

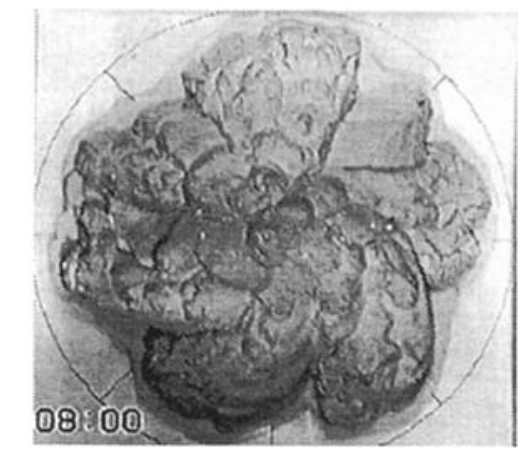

b

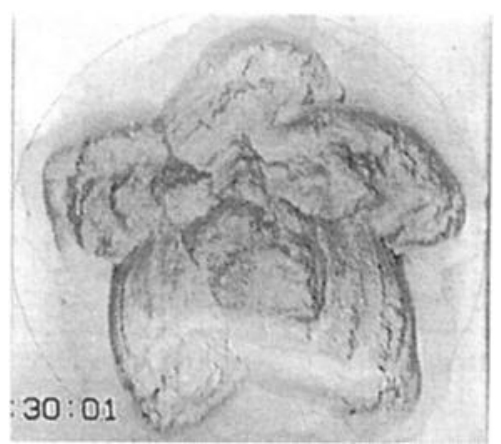

d

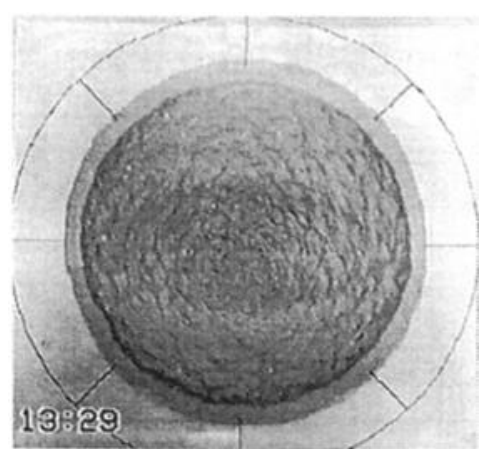

Figure 1. Top views of dome simulations: (a) experiment $95-25$, for $Q=0.60 \mathrm{~cm}^{3} / \mathrm{s}, T_{a}=4.9^{\circ} \mathrm{C}$, and $\Psi_{B}$ $=0.09$; (b) experiment $95-18$, for $Q=1.13 \mathrm{~cm}^{3} / \mathrm{s}, T_{a}=10.8^{\circ} \mathrm{C}, \Psi_{B}=0.21$; (c) experiment $95-21$, for $Q=$ $1.10 \mathrm{~cm}^{3} / \mathrm{s}, T_{a}=14.9^{\circ} \mathrm{C}$, and $\Psi_{B}=1.3$; and (d) experiment $95-20$, for $Q=1.10 \mathrm{~cm}^{3} / \mathrm{s}, T_{a}=20^{\circ} \mathrm{C}$, and $\Psi_{B}=$ 30. In all photos the concentric circles are spaced $5 \mathrm{~cm}$ apart and times are shown in minutes and seconds.

lobes joined to a central core (Figures $\mathrm{Ib}$ and $2 \mathrm{~b}$ ), leading to their designation as lobate domes. The lobate character of the extrusion became evident early in these experiments, with the lobes emerging along steeply dipping fractures and growing horizontally by sliding along the floor of the tank (even when this was very rough). Movement is normally concentrated in a single lobe, although occasionally several may advance concurrently. At later stages of development, additional projections emerged on top of earlier material. Because fracturing localized along a smaller number of zones and lobes became more exogenous in nature as the dome grew larger, the surface appearance of the dome took on a progressively smoother texture.

In the next group of experiments (Figures $1 \mathrm{c}$ and $2 \mathrm{c}$ ), cooling played still less of a role, and the domes acquired more circular planforms with smoother and lower cross-sectional profiles. Wedge-shaped segments bounded by subradial fractures advanced through a combination of endogenous and exogenous growth. In contrast to lobes, segments typically advanced continuously and as a group, maintaining a relatively uniform flow front. The surfaces of these lobes were covered by transverse, step-like knobs that increased in wavelength as the dome enlarged. Early in the experiments the wedge-bounding cracks appeared as straight-sided segments radiating from the vent area; as the domes got larger, these curved in a spiral pattern and terminated progressively farther from the center. The combination of knobs and arcing fractures tended to break up the dome surface at a smaller scale than in the colder or slower experiments described above. The prevalence of relatively straight plates and ridges caused us to refer to these domes as platy.
Experiments with the warmest water and/or largest extrusion rates produced near-circular flows with low cross-sectional profiles like those shown in Figures $1 \mathrm{~d}$ and $2 \mathrm{~d}$. The surfaces of these extrusions were divided by shallow curvitinear fractures into small rhombohedral areas similar to those described by Blake [1990] in a series of isothermal kaolin simulations of the growth of low lava domes. Later dissection of these domes revealed only thin discontinuous patches of solidified crust near the flow margins. The ring of debris around the periphery of the flow resembling a talus apron is kaolin powder that came out of suspension owing to the relatively warm bath temperature and accumulated ahead of the advancing flow front. Cooling played no significant role under these conditions, and raising the ambient temperature or effusion rate still higher would have had no further effect. Only the interior slurry yield strength (and any preexisting topography) controlled the flow relief. Because these extrusions tend to advance uniformly in all directions. we call them axisymmetric domes.

\subsection{Scaling Relations}

The above four experiments illustrate the range of morphologic and textural features formed in our kaolin/PEG simulations. In contrast to natural domes, for the laboratory extrusions we can measure not only their final appearance but also their material properties and temporal evolution. In our earlier laboratory models using PEG injected into cold sucrose solution [Fink and Griffiths, 1990, 1992] we showed how flow morphology could be predicted from the ratio $\Psi$ of a timescale for advection $t_{t}$ to a timescale for solidification $t_{S}$ 
a
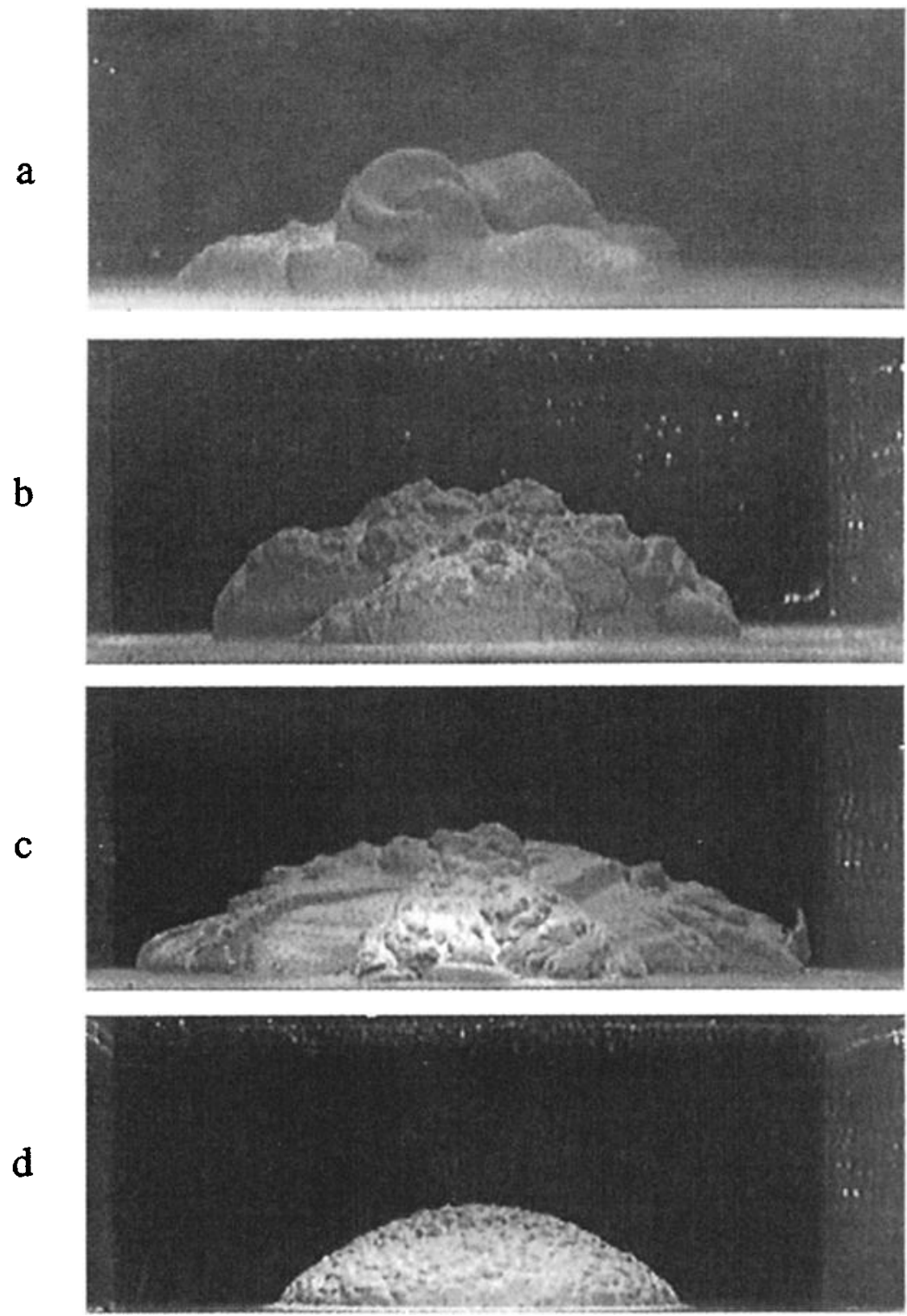

Figure 2. Side views of the same dome experiments seen in Figures la-1d. Note that the axisymmetric dome (Figure 2d) is shown at a relatively earlier stage than the other three domes. At later times the profile became noticeably flatter.

where $t_{A}$ is the time needed for the viscous flow to advance a distance equal to its thickness, $t_{S}$ is the time necessary for fresh magma exposed at the surface to reach its solidification temperature, and $\Psi=t_{S} / t_{A}$. Modifying our earlier analysis to take into account the yield strengths of clay/wax slurries gives a different expression for the advection time, $t_{A}=$ $(g \Delta \rho / \sigma)^{3} Q$. Hence we defined a new dimensionless number appropriate for flows whose interiors have a significant strength prior to cooling:

$$
\Psi_{B}=t_{S} / t_{A}=(g \Delta \rho / \sigma)^{3} Q t_{S}
$$

where $g$ is the acceleration due to gravity, $\Delta \rho$ is the density contrast between the flow and its environment, $\sigma$ is the magma strength (in the dome interior), and $Q$ is the eruption rate [Griffiths and Fink, 1997].

In our clay/wax experiments we find that morphologic types are associated with well-defined ranges of $\Psi_{B}$ : spiny domes have $0.01<\Psi_{B}<0.12 \pm 0.02$ (where the lower limit corresponds to a transition from spines to "noodles"), lobate domes have $0.12<\Psi_{B}<0.9 \pm 0.3$, platy domes have $0.9<\Psi_{B}<15 \pm 5$, and axisymmetric domes have $15<\Psi_{B}<100$ (where the upper limit coincides with conditions beyond which there is no noticeable solidification) [Griffiths and Fink, 1997]. If our previous hypothesis is correct, then natural lava domes with rheologic and cooling behaviors dynamically similar to those of the clay/wax slurries should have values of $\Psi_{B}$ similar to those of the laboratory morphologies. We can also check the validity of this correspondence between model and natural domes by using it to estimate the yield strengths of the vent magmas for natural domes and comparing these with values determined previously by other methods.

Experiments also allow us to compare the overall shapes of model domes with theoretical relationships for idealized rheologic end-members. Assuming self-similar growth in these 
idealized cases, the rates at which height $(h)$ or radius $(r)$ vary with time $(t)$, or height varies with radius, should take on diagnostic power law forms which depend upon whether the spreading of a flow is limited by the strength or viscosity of its interior or a surface layer [Huppert, 1982; Blake, 1990; Griffiths and Fink, 1993]. For example, an axisymmetric flow of an isothermal Newtonian viscous fluid (in which the outward force due to gravity is resisted only by the viscosity of the flow's interior) which is being supplied at a constant rate onto a horizontal plane will have a radius that varies as the square root of time and a height that is constant in time [Huppert, 1982]. For the case of a solidifying Bingham plastic in which the strength of the cooling surface crust provides most of the resistance to outward spreading [Griffiths and Fink, 1993], $r$ will vary as $t^{3 / 8}$, while dome height will vary as $t^{1 / 4}$ and as $r^{2 / 3}$. Corresponding predictions are also available for cases in which the effusion rate varies with time. Measurements of how the volume, radius, and height change with time for a given natural or simulated lava dome can potentially be used in this way to specify which rheological model best describes the dome's properties.

In our experiments with solidifying kaolin/wax slurries [Griffiths and Fink, 1997] we found that when solidification is slower than lateral spreading $\left(\Psi_{B}>1\right)$, the three power law exponents took fixed values $\left(r \sim t^{0.42 \pm .02}, h \sim t^{0.25 \pm .01}\right.$, $h-r^{0.60 \pm .01}$ ) that are consistent with those predicted for spreading driven by gravity and controlled by a strong and developing crust (as described above and by Griffiths and Fink [1993], the approximate model predicts exponents 0.38 , 0.25 , and 0.67 , respectively). However, the new experimental results are not sufficiently different from the model predictions and measurements for the isothermal Bingham case (which give exponents $0.40,0.20$, and 0.50 , respectively [Blake, 1990]) for a definite conclusion to be drawn on the role of the cooled crust relative to interior strength. Thus it can only be concluded that the solidifying laboratory domes under these conditions were dominated by a yield strength and not a viscosity, a fact already clear from the observation that domes ceased to spread when the vent flux was turned off. For experiments in which solidification was rapid compared to spreading $\left(\Psi_{B}<1\right)$, on the other hand, the power law exponents varied with $\Psi_{B}$. In particular, the height was an increasingly strong function of radius for smaller $\Psi_{B}$ (possibly approaching $h \sim r$ at $\Psi_{B}<0.1$ ). This behavior is consistent with conditions transitional between those under which spreading is driven by gravity and those under which overpressure within the dome is dominant. Corresponding dimensional data derived from observations of the growth of natural domes should help specify their rheologic state and delimit their $\Psi_{B}$ values at the time they were emplaced.

\section{Morphologic Classification of Lava Domes}

In order to use our experimental results to interpret natural lava domes, we must first evaluate how well the above classification scheme for solidifying kaolin/PEG slurries applies to magmatic extrusions. Here we briefly review a few previous attempts to catalog different types of domes and then list those characteristics that we feel may be used to place natural domes into the laboratory-based categories.

To the nonspecialist, all lava domes look more or less alike: roughly circular, steep-sided accumulations of fractured blocks surrounded by aprons of talus. Closer examination reveals many variations on this theme. Overall plan shapes may be ovoid to highly elongate, depending on underlying slope and conduit geometry. Cross-sectional profiles can range from conical to hemispherical to nearly flat. Flow surfaces may be described as smooth, striated, fractured, folded, spiny, or platy. Blocks may be glassy, holocrystalline, microcrystalline, or vesicular; uniform or variable in size; angular or rounded; and black, gray, brown, pink, tan, or white in color.

Previous workers have variously tried to explain the morphology, texture, dynamics and hazards of lava domes. In the first extensive treatise on the topic, Williams [1932] synthesized his own and most previous observations of domes and concluded that their shapes depended primarily on total volume, eruption rate, rate of solidification, and local topography; dome chemistry, which ranges from rhyolite to basalt, was not found to be a controlling factor. Williams distinguished between exogenous and endogenous growth, which he attributed mainly to effusion rate, and recognized that upheaved plugs formed from slowly extruded lava that had already solidified in the conduit. He emphasized the role of fracturing in establishing both the final morphology of a dome and its tendency to undergo explosive disruption. A lack of detailed deformation data or longitudinal studies of dome growth prevented Williams from presenting a quantitative classification scheme.

More recent studies have tried to relate dome morphology and dynamics to magma rheology and eruption conditions. For example, Huppert [1982] and Huppert et al. [1982] explained detailed observations of the growth of the Soufrière dome on the island of St. Vincent through comparison with a set of laboratory experiments using isothermal Newtonian fluids. These studies concluded that the changing shape of a dome could be used to estimate the average or bulk viscosity of its lava. Blake [1990] attempted to incorporate non-Newtonian effects and presented a model for dome growth based on a survey of morphologic data from the literature and laboratory simulations using isothermal Bingham slurries of kaolin and water. He related the aspect (height to diameter) ratios of four classes of domes (upheaved plugs, Peléean, low, and coulée) to the estimated yield strengths of their magmas. He also quantified other relationships between each of these types and their emplacement conditions, but the applicability of his work was limited by its inability to account for the effects of cooling.

The dome categories listed by Williams [1932] and Blake [1990] have similarities to those discerned in our kaolin/PEG experiments. "Peléean domes" and "upheaved plugs" occur at very low extrusion rates and may be covered by spine-like protrusions, just like the "spiny" laboratory domes. Blake's "low" lava domes (Williams' "endogenous" domes) have nearly flat, smooth profiles and advance by radial spreading, like our "axisymmetric" domes. Blake's "coulées" refer to stubby, elongate flows that are transitional between circular domes and channelized lava streams. Because our slurry experiments to date have all been carried out in horizontal tanks, we have not produced an equivalent to this type of dome.

Classification of volcanic structures is subjective. The two additional dome categories recognized in our experiments, lobate and platy, form part of a morphologic continuum controlled by extrusion and cooling rate. Assigning any given magmatic dome to one of the four laboratory-based types may be problematic, especially because natural domes rarely have effusion rates or rheologic properties that remain constant 
throughout extrusion. However, if we can demonstrate dynamic similarity between kaolin/PEG domes and magmatic domes, then to the extent that we can classify the latter, we may be able to better specify their eruption rates and/or physical properties. Here we list those structural and textural characteristics of lava domes that may help place them into one or more of the laboratory-based categories.

\subsection{Spiny Domes}

Spiny domes tend to be tall and very steep sided, with relatively smooth upper surfaces covered by small blocks and ash. Their tops are commonly punctured by one or more subvertical spines with smooth, curving sides, diameters ranging from meters to tens of meters, and heights ranging from meters to hundreds of meters. Spines may be covered with striations scraped into their sides by asperities in the cracks through which they emerged from the flow interior. Most spine-dominated domes are roughly circular in map view and conical in profile. Generally, spines form directly over the active vent, with only one rising at a given time. These features are inherently unstable and routinely collapse to piles of rubble. Continued extrusion of a spiny dome on a steep slope may generate a thick lava flow, or coulée, that may travel for several kilometers. Both the central dome and the more distal coulée tend to produce pyroclastic flows when their flow fronts collapse (e.g., Santiaguito [Rose et al., 1977]).

\subsection{Lobate Domes}

Lobate domes are made up of a number of distinct portions that come out sequentially from a central vent (although a few may be active at any time), with each advancing more or less in a single direction. The initial accumulation of these "exogenous" lobes, whose widths typically range from 100 to $500 \mathrm{~m}$, may result in a dome with a relatively equant or stellate outline resembling a cloverleaf. Near the beginning of its growth a dome may inflate endogenously before individual lobes begin to emerge. In these cases the initial dome becomes one of the lobes, each of which extrudes for a time and then becomes dormant as others take up the continuing efflux from the vent. Like spines, individual exogenous lobes can have smooth or striated surfaces and extrude from the interior along fractures in the dome's carapace. However, instead of being emplaced vertically, most lobes advance subhorizontally, acquiring grooves and ridges that parallel the direction of movement.

In addition to flow-parallel striations, lobe surfaces may occasionally exhibit discontinuous, poorly defined, transverse corrugations with wavelengths of the order of tens of meters [Fink, 1980]. Local spreading centers, or "crease structures" [Anderson and Fink, 1992], may occur either directly over the vent or at other sites where a lobe surface is being stretched apart [Swanson et al., 1987]. Crease structures have paired, smooth, upwardly convex surfaces that move laterally outward from the central axis. In some cases they develop their own centimeter-scale striations that parallel the midline and reflect incremental inward growth of the fracture. Although brittle failure may be extensive in lobate domes, it occurs at a relatively late stage in their emplacement, so that there is little opportunity for comminution or rounding of blocks. The lack of tall spines that crumble to rubble also means that lobate surfaces tend to be less littered with small blocks than those of spiny domes. The smooth portions of lobate domes, most of which form by spreading along crease structures, may range up to several hundred square meters in area. Collapse of flow fronts of lobate domes can generate explosive phenomena, especially when they are traversing steep slopes.

\subsection{Platy Domes}

In contrast to lobate domes, platy domes that emerge on gentle slopes have less well defined lobes which may merge with a circular central region rather than extend all the way back to the vent. Smooth areas are more restricted and take the form of angular ridges oriented both perpendicular and parallel to the local flow direction. Relatively straight, transverse ridges develop as folds at sites of compression, whereas flow-parallel ridges come out as "squeeze-ups" through gently curving, subradial fractures as the dome margin undergoes circumferential stretching. The combination of folding and fracturing leads to a surface that is broken up into smaller, flat, plate-like elements, of the order of tens of meters. Surface breccia is more common than on spiny or lobate domes. Because individual lobes are smaller and less well developed, the outlines of platy domes are more circular than lobate ones (or more elliptical on steep slopes). Cross sections tend to be more rounded and lower than spiny or lobate domes.

\subsection{Axisymmetric Domes}

Axisymmetric domes have the most regular outlines, the lowest relief, and surfaces that tend to be the most heavily covered by small blocks. Their morphology suggests deformation behavior that is transitional between Bingham plastics and viscous fluids. Laterally extensive, transverse folds with relatively short wavelengths $(1-5 \mathrm{~m})$ may parallel their entire margins, and radial fractures are limited to those portions of the flow nearest the front or directly over the vent. Talus aprons of uniform width made of relatively small blocks encircle the flows. Surface blocks may be highly variable in color, reflecting different degrees of vesiculation and crystallization. On steep slopes, axisymmetric domes commonly form marginal levees as well as transverse folds. This category corresponds to Williams' [1932] and Blake's [1990] low or coulee type domes, depending on whether or not they are advancing down slopes. Emplacement of these flows is not commonly accompanied by violent endogenic explosive processes, although some exhibit explosion craters on their upper surfaces that appear to result from local concentration of volatiles in their interiors. Some prehistoric flows of this morphologic type are associated with relatively restricted block and ash flow deposits.

\section{Observations of Active Lava Domes}

In section 3 we listed those characteristics of natural domes that might place them into categories that correspond to those defined in our laboratory simulations. One test of the accuracy of this correspondence comes from an evaluation of the extrusion rates and final morphologies of active domes that were well documented during their growth. We have identified eight dome eruptions where emplacement rates, compositions, and final morphologies are known: Soufrière of St. Vincent (active in 1979), Mount St. Helens (1980-1986), Pinatubo (1992), Unzen (1991-1995), Santiaguito (1922-1997), Merapi 
Table 1. Well-Documented Dome Eruptions

\begin{tabular}{|c|c|c|}
\hline Dome & Date & Reference(s) \\
\hline Mont Pelée, Martinique & 1902 & Lacroix [1904] \\
\hline Mont Pelée, Martinique & $1929-1932$ & Perret $[1937]$ \\
\hline Santiaguito, Guatemala & 1922 to present & $\begin{array}{l}\text { Rose [1972, 1973, 1987], Rose et al. [1977], Sanchez et al. } \\
\quad[1992], \text { and Anderson et al. }[1995]\end{array}$ \\
\hline Showa Shinzan, Japan & 1945 & Masao [1995] \\
\hline Mt. Lamington, PNG & 1951 & Toylor $[1958]$ \\
\hline Bezymianny, Kamchatka & 1955 to present & $\begin{array}{l}\text { Bogoyovlenskaya and Kirsanov }[1981,1987] \text { and Braitseva et } \\
\text { al. }[1991]\end{array}$ \\
\hline Soufrière, St. Vincent & 1979 & $\begin{array}{l}\text { Shepherd et al. [1979], Shepherd and Sigurdsson [1982], } \\
\text { Huppert [1982], and Huppert et al. [1982] }\end{array}$ \\
\hline Mount St. Helens, Washington & $1980-1986$ & $\begin{array}{l}\text { Swanson et al. [1987], Chadwick et al. [1988], Anderson and } \\
\text { Fink [1990], Fink et al. [1990], and Swanson and Holcomb } \\
\text { [1990] }\end{array}$ \\
\hline Mount St. Augustine, Alaska & 1986 & Swanson and Kienle [1988] \\
\hline Merapi, Indonesia & 1987 to present & Young et al. [1994], and Ratdomopurbo [1995] \\
\hline Galeras, Colombia & 1991-1992 & Calvache and Williams [1997] \\
\hline Unzen, Japan & 1991-1995 & Nakada and Fujii [1993], and Nakada et al. [1995] \\
\hline Redoubt Alaska & 1991 & Miller [1994], and Power et al. [1994] \\
\hline Pinatubo, Philippines & 1992 & Daag et al. [1996] \\
\hline Montserrat, West Indies & 1995 to present & $\begin{array}{l}\text { R. Stewart (personal communication, 1996), and Global } \\
\text { Volcanism Network reports, 1996-1997 (available from } \\
\text { AGU) }\end{array}$ \\
\hline
\end{tabular}

(1994-1997), Redoubt (1989-90), and Montserrat (19951997). These are a representative subset of the dome eruptions that have been well documented in the literature (Table 1). For some of these extrusions, growth rate data are available both for individual lobes and for the entire structure; for others, information was collected only for a selected period of the growth. In addition, known chemical compositions allow eruption temperatures $\left(T_{e}\right)$ to be estimated, which, in turn, bound $t_{S}$, the timescale for solidification. This timescale is found from a heat transfer computation [Fink and Griffiths, 1992] and depends on the glass transition temperature $\left(T_{g}\right)$.
The values of $t_{S}$ assuming $T_{g}=700 \pm 50^{\circ} \mathrm{C}$ are shown in Figure 3. Combining morphologic observations with estimates of eruption rates and solidification timescale (the latter obtained from estimates of eruption temperatures) and assuming that natural domes behave in a similar way to our laboratory analogs, we are able to construct a plot (Figure 4) that defines each dome's yield strength. These strength estimates can then be compared with those determined in the laboratory [e.g., Murase et al., 1985] or by other morphologic methods [e.g.. Hulme, 1974], providing an independent test of the applicability of the clay/slurry analogs to natural domes.

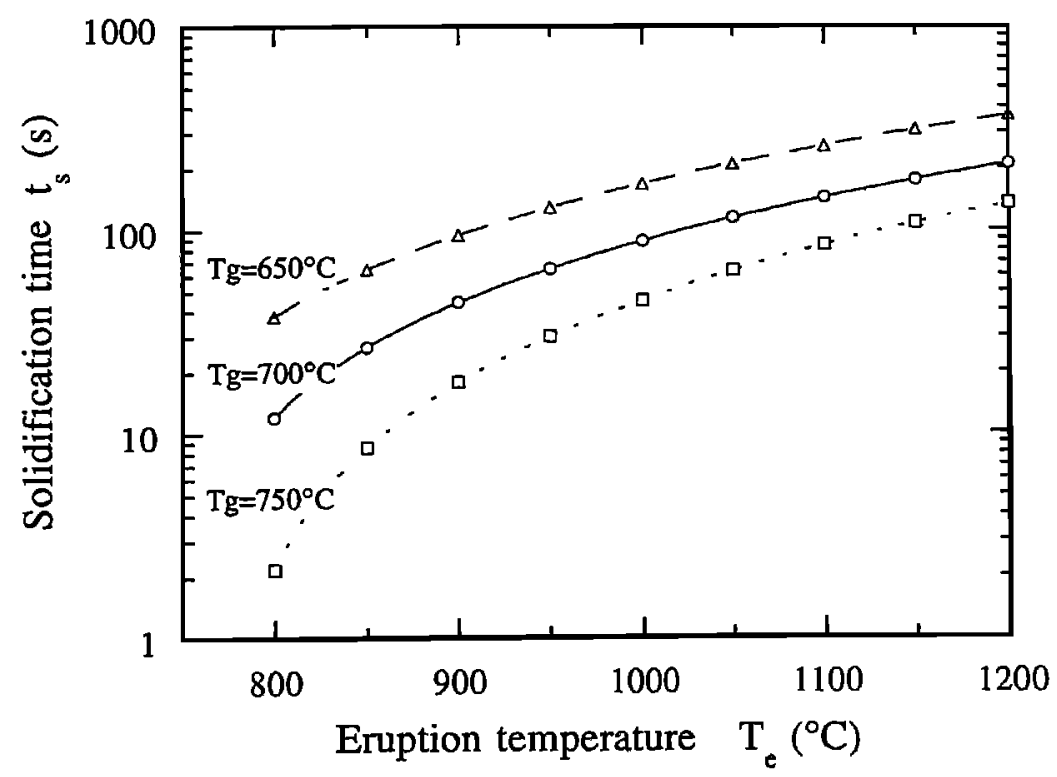

Figure 3. Plot of lava solidification timescale $\left(t_{S}\right)$ versus eruption temperature $\left(T_{e}\right)$ for different values of glass transition temperature $\left(T_{g}\right)$. For details of the definition and calculation of $t_{S}$ see Griffiths and Fink [1992]. 


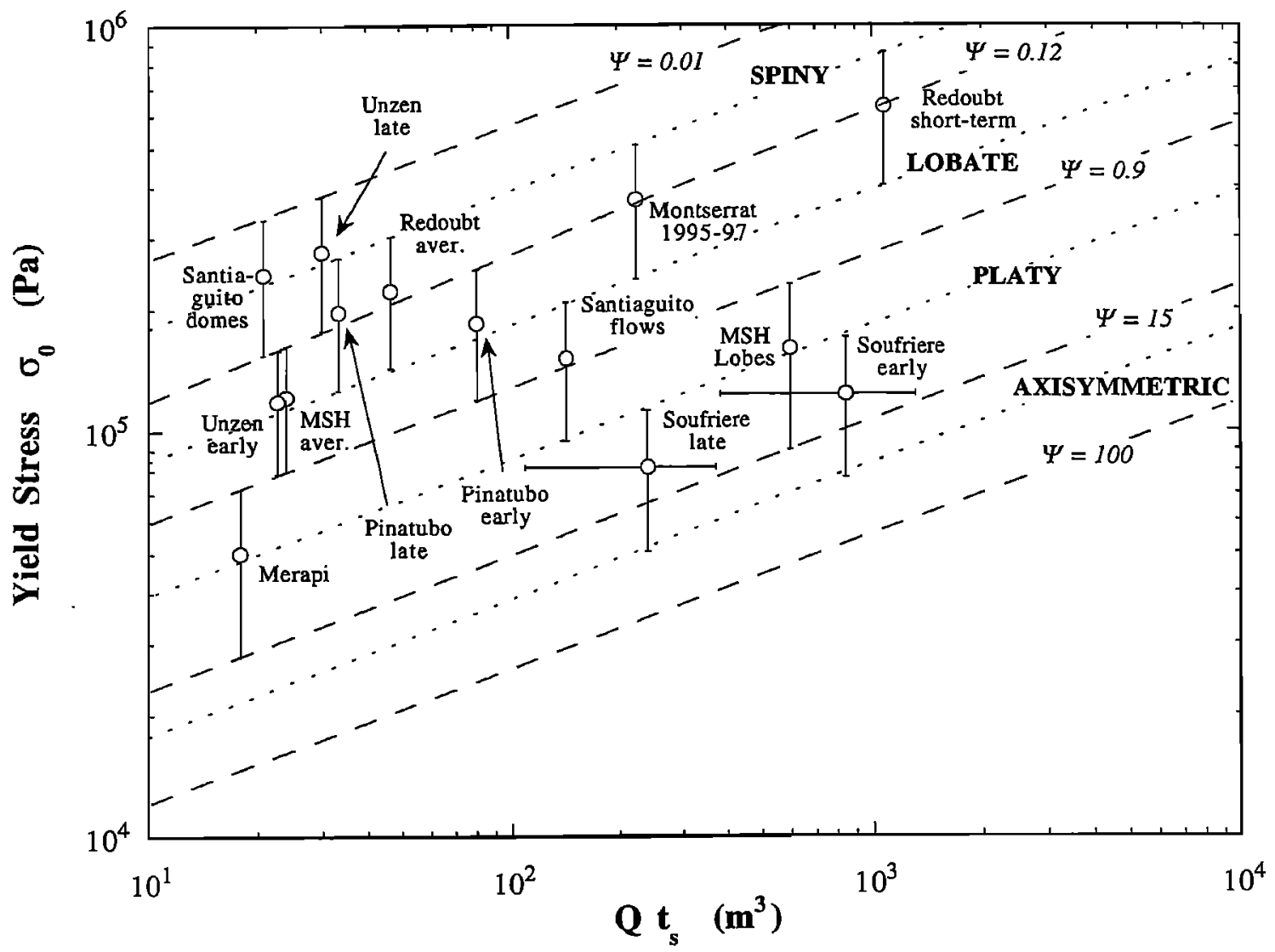

Figure 4. Morphological classification of natural lava domes and inferred ranges of the dimensionless parameter $\Psi_{B}$ as a function of the quantity $Q t_{S}$ (the volume of lava erupted in one period $t_{S}$ ) and interior yield strength $\sigma$. Heavy dashed lines of constant $\Psi_{B}$ have been plotted against $Q t_{S}$ and $\sigma$ according to (1); then each dome is graphed according to its estimated values of $Q t_{S}$ and $\Psi_{B}$. Dotted lines show limiting $\Psi_{B}$ values of transitional morphologies taken from Table 2 (e.g., lobate/platy). The yield strength of magmas is treated as unknown and may be estimated from the graph. Error bars showing the uncertainties in the quantity $Q t_{S}$ have been omitted for most cases in the interest of clarity and are generally smaller than those shown for the Soufrière dome.

\subsection{Soufrière of St. Vincent}

The generally circular shape, low profile, lack of prominent fractures, and uniform blanket of small surface blocks found on the 1979 Soufrière andesite dome (Figure 5) [Shepherd et al., 1979; Huppert, 1982; Huppert et al., 1982] place it between the axisymmetric and platy categories. We estimate that $3<\Psi_{B}$ $<30$, based on its morphology (Table 2). This dome was extruded in two stages: an initial 3-week period of relatively high eruption rate $\left(Q=7.7 \mathrm{~m}^{3} / \mathrm{s}\right)$, followed by 4 months at considerably lower rates (averaging $Q=2.2 \mathrm{~m}^{3} / \mathrm{s}$ ). The entire structure had a relatively smooth profile implying continuous emplacement. If we use these two eruption rates, along with $T_{e}$ $=950 \pm 50^{\circ} \mathrm{C}$ (so that $50<t_{S}<170 \mathrm{~s}$ ), then yield strengths calculated for the early and late periods are around 0.6 to $2.0 \mathrm{x}$ $10^{5} \mathrm{~Pa}$ and 0.4 to $1.3 \times 10^{5} \mathrm{~Pa}$, respectively. These are remarkably consistent with published estimates by Blake [1990] and Griffiths and Fink [1993] based on applications of the isothermal Bingham modeling to data for growth of dome volume and height.

\subsection{Mount St. Helens}

The Mount St. Helens dome has an overall morphology that places it in the lobate category (Figure 6)(hence $0.12<\Psi_{B}<$
0.9), while some individual lobes have characteristics more typical of the platy regime (hence we estimate $0.3<\Psi_{B}<3$; Table 2). For an average eruption rate over 6 years of $0.4 \mathrm{~m}^{3} / \mathrm{s}$ [Swanson et al., 1987; Swanson and Holcomb, 1990; Fink et al., 1990] and a solidification timescale $t_{S}=60 \mathrm{~s}\left(T_{e} \sim 930^{\circ} \mathrm{C}\right)$, Figure 4 indicates an interior yield strength for the entire dome of around 0.8 to $1.6 \times 10^{5} \mathrm{~Pa}$. During the growth of individual lobes the effusion rates could be much greater, up to 10 $\mathrm{m}^{3} / \mathrm{s}$. This observation is consistent with the larger value of $\Psi_{B}$ inferred independently from the morphology of individual lobes, which leads to $\sigma=0.9$ to $2.3 \times 10^{5} \mathrm{~Pa}$. The slight discrepancies between these two sets of estimates may be related to the different ways eruption rates are calculated. In our experiments, eruption style is based on the overall dome rather than individual lobes, whereas at Mount St. Helens, dome growth was episodic, so that each lobe might be considered as a separate eruption. Application of Blake's [1990] isothermal Bingham model to detailed observations of the growth of volume and height of the October 1986 lobe point to a shear strength of the interior lava of $1.1 \times 10^{5} \mathrm{~Pa}$ [Griffiths and Fink, 1993], similar to that determined here from the overall shape. This value is also similar to that obtained in the laboratory for material from this dome heated to $950^{\circ} \mathrm{C}$ [e.g., Murase et al., 1985]. 


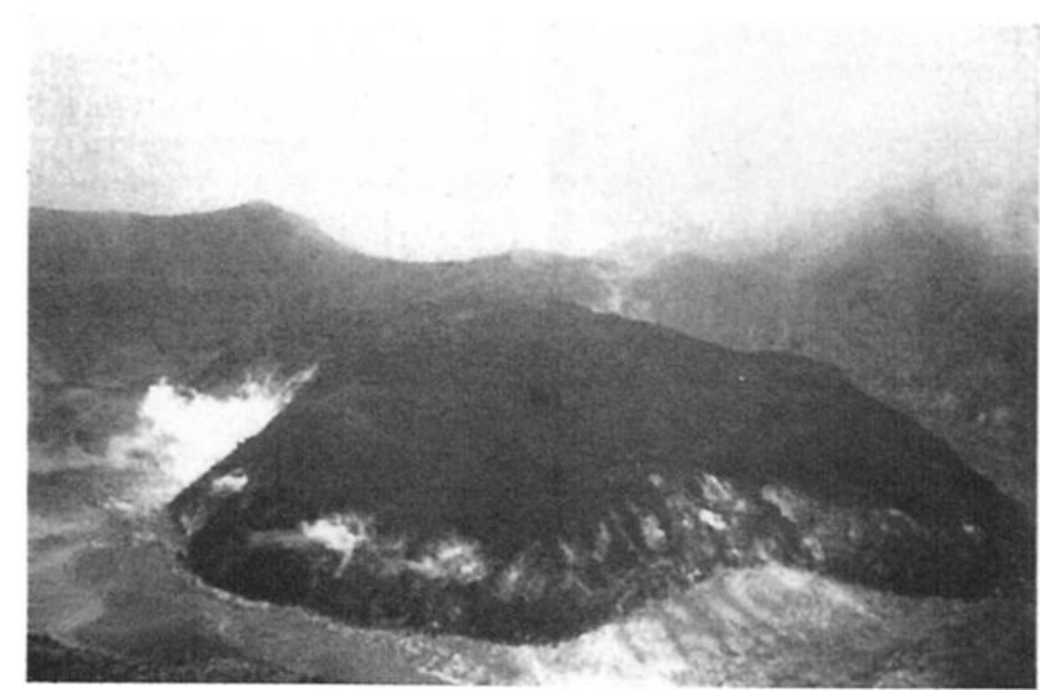

Figure 5. Soufrière of St. Vincent dome, 1979 (photo courtesy of R. Fiske). Dome is approximately $850 \mathrm{~m}$ across and $130 \mathrm{~m}$ high.

\subsection{Mount Pinatubo}

Thirteen months after the cataclysmic eruption of Mount $\mathrm{Pi}$ natubo, a small andesitic lava dome appeared in the partially flooded crater. Ten sets of aerial observations allowed growth rates to be estimated and morphology to be classified [Daag et al., 1996]. The dome attained a height of $40 \mathrm{~m}$, radius of $200 \mathrm{~m}$, and volume of $1.8 \times 10^{6} \mathrm{~m}^{3}$. Two distinct rates of growth were observed: around $8 \times 10^{3} \mathrm{~m}^{3} / \mathrm{d}\left(0.9 \mathrm{~m}^{3} / \mathrm{s}\right)$ for the first 3 weeks, and $3 \times 10^{3} \mathrm{~m}^{3} / \mathrm{d}\left(0.37 \mathrm{~m}^{3} / \mathrm{s}\right)$ for the next 3 months. Its relatively steep profile, migrating locus of spreading, prevalence of crease structures and other fractures as well as occasional spines up to $20 \mathrm{~m}$ high all suggest that this dome belongs in the lobate category for its initial emplacement, followed by a transitional spiny to lobate category in the later, slower growth stage $\left(0.03<\Psi_{B}<0.3\right.$; Table 2). Using $T_{e}=1000^{\circ} \mathrm{C}$ gives $t_{S}=90 \mathrm{~s}$, and $Q=0.9 \mathrm{~m}^{3} / \mathrm{s}$ gives $Q t_{S}=81 \mathrm{~m}^{3}$ for the early stage, while $Q=0.37 \mathrm{~m}^{3} / \mathrm{s}$ gives $Q t_{S}=33 \mathrm{~m}^{3}$ for the later stage. Figure 4 suggests both stages had roughly the same range of yield strengths (early is 1.2 to $2.5 \times 10^{5} \mathrm{~Pa}$; late is 1.3 to $2.7 \times 10^{5} \mathrm{~Pa}$ ), so that morphologic changes were most likely caused by the observed decline in eruption rate.

\subsection{Mount Unzen}

An extensive series of aerial photographs taken of the Mount Unzen dome from 1991 through 1995, as well as almost daily helicopter surveillance by members of the Shimabara Earthquake and Volcano Observatory, provide another thorough documentation of a dome's emplacement [Nakada and

Table 2. Assumed $\Psi$ Values for Different Dome Morphologies

\begin{tabular}{lcr}
\hline Type & $\Psi_{\min }$ & $\Psi_{\max }$ \\
\hline Spiny & 0.01 & 0.12 \\
Spiny/lobate & 0.03 & 0.3 \\
Lobate & 0.12 & 0.9 \\
Lobate/platy & 0.3 & 3.0 \\
Platy & 0.9 & 15 \\
Platy/axisymmetric & 3.0 & 30 \\
Axisymmetric & 15 & 100 \\
\hline
\end{tabular}

Fujii, 1993]. Large lobes and a central spine, along with the prevalence of smooth extruded surfaces, were obvious during our own inspection of the dome in 1995, soon after the eruption ceased. Morphologic characteristics of the Unzen dome place it in the lobate category during its early stages (Figures $7 \mathrm{a}$ and $7 \mathrm{~b}$ ) and the spiny category as it waned. We assume that the Unzen dacite has the same eruption temperature $\left(T_{e}=\right.$ $\left.950^{\circ} \mathrm{C}\right)$ and $t_{S}(=65 \mathrm{~s})$ as that in the Mount St. Helens dome. The eruption rates averaged over early and late periods of growth were $Q_{A V}=4.6 \mathrm{~m}^{3} / \mathrm{s}$ (lobate) and $Q_{A V}=0.35 \mathrm{~m}^{3} / \mathrm{s}$ (spiny), respectively. Figure 4 shows that $\sigma$ should have been in the range of around 0.8 to $1.6 \times 10^{5} \mathrm{~Pa}$ early in the emplacement and 1.8 to $3.8 \times 10^{5} \mathrm{~Pa}$ later. This progression indicates that a significant change in magma rheology probably accompanied (and perhaps caused) the observed decrease in eruption rate.

\subsection{Santiaguito}

The first site where unequivocal evidence was found that lava front collapse could form pyroclastic flows was the San-

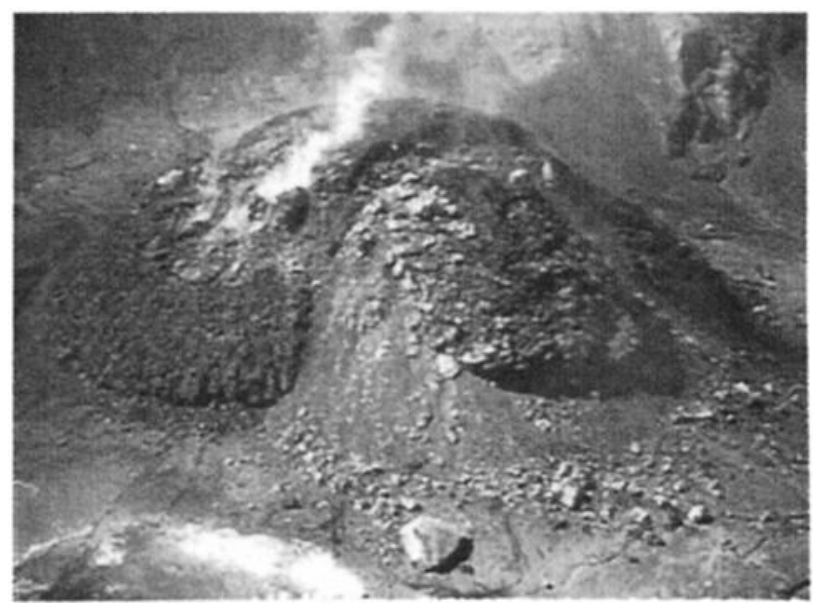

Figure 6. Mount St. Helens dome in September 1981 showing several overlapping lobes. Dome approximately $160 \mathrm{~m} \mathrm{high}$ (photo courtesy of Lyn Topinka, U. S. Geological Survey). 


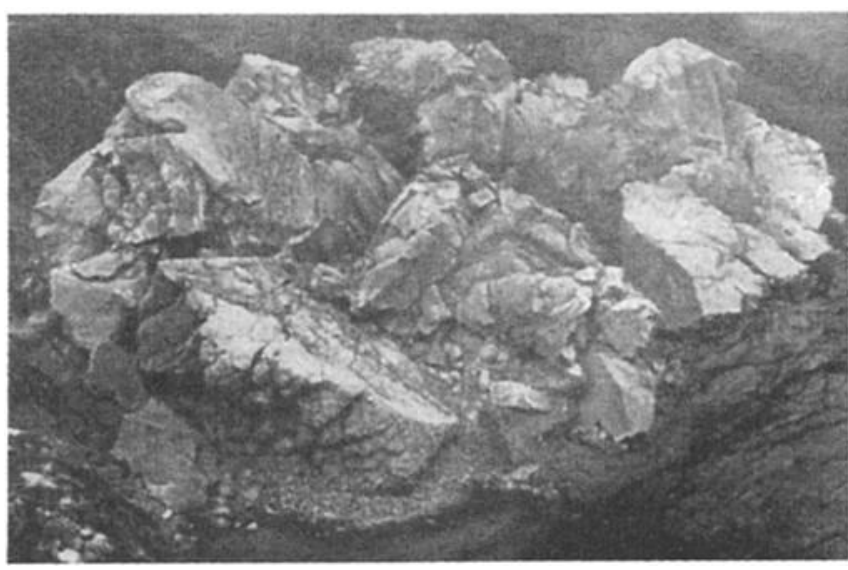

Figure 7a. Early stage of Unzen dome, May 1991. Dome dimensions approximately $100 \mathrm{~m}$ long by $60 \mathrm{~m}$ wide by $40 \mathrm{~m}$ high (photo courtesy of S. Nakada).

tiaguito dacite dome complex (Figure 8) [Rose et al., 1977]. This group of four overlapping crystal-rich domes has actively grown for over 70 years with variable eruption rates from around 0.32 to $2.22 \mathrm{~m}^{3} / \mathrm{s}$ corresponding to different eruption

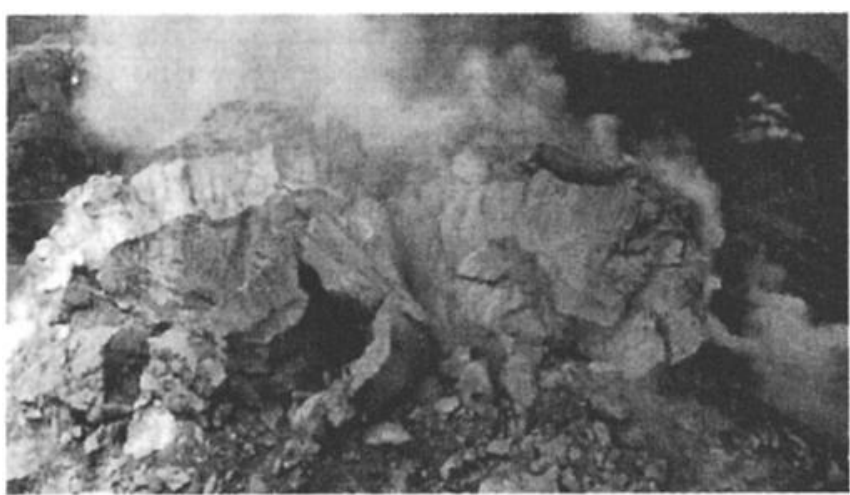

Figure 7b. Crease structure on Unzen dome, September 1991 (photo courtesy of S. Nakada). styles. The 3-5 year long, high eruption rate spurts have occurred roughly every $15-20$ years $[$ Rose, 1972,1987$]$ and have been accompanied by enhanced explosive activity and accelerated growth of adjacent lava flows. These flows have lobate to platy morphology, whereas the four domes are spiny. Combining these morphologic observations with the same dacite values of $T_{e}\left(=950^{\circ} \mathrm{C}\right)$ and $t_{S}(=65 \mathrm{~s})$ used for the Mount St. Helens and Unzen magmas, the two eruption rates cited above imply that $\sigma=0.9$ to $2.1 \times 10^{5} \mathrm{~Pa}$ for the Santiaguito flows and 1.5 to $3.3 \times 10^{5} \mathrm{~Pa}$ for the domes. As at Mount Unzen, the morphologic changes appear to be related to variations in lava rheology as well as eruption rate.

\subsection{Merapi}

Lava dome growth and collapse have been familiar attributes of the eruptive activity of Mount Merapi for over 70 years, although in the past 5 years the geometry of the edifice has made gravitational failure and explosive decompression increasingly likely. Fears of such hazards were confirmed in November 1994 when more than 30 people attending a wedding on the flanks of the volcano were killed by a pyroclastic surge generated immediately after the front of the dome broke away [Young et al., 1994; Sukyhar, 1995]. Photographs as well as our own field observations in October 1995 place this andesitic dome in the platy category (Figure 9). Limited survey data collected by Ratdomopurbo [1995] give flow rates of around $0.2 \mathrm{~m}^{3} / \mathrm{s}$. Combining these with $t_{S}=90 \mathrm{~s}$, inferred from a $T_{e}=$ $1000^{\circ} \mathrm{C}$, leads to a calculated yield strength of around 0.3 to $0.7 \times 10^{5} \mathrm{~Pa}$. This comparatively low value is unexpected, given the microlite concentrations of $45-60 \%$ measured in the 1995 lava by Hammer and Cashman [1998]. Such a discrepancy could indicate that the morphology we observed in 1995 was atypical of the dome's normal appearance, that the eruption rate measured in 1994 was an underestimate of that during the formation of the 1995 dome, or that these microlite concentrations have little effect on the bulk yield strength. Alternatively, the domes formed by continuous eruption since the late 1980s might be interpreted as lobes of an extrusion confined by the crater walls, in which case the strength estimate would be around $10^{5} \mathrm{~Pa}$.

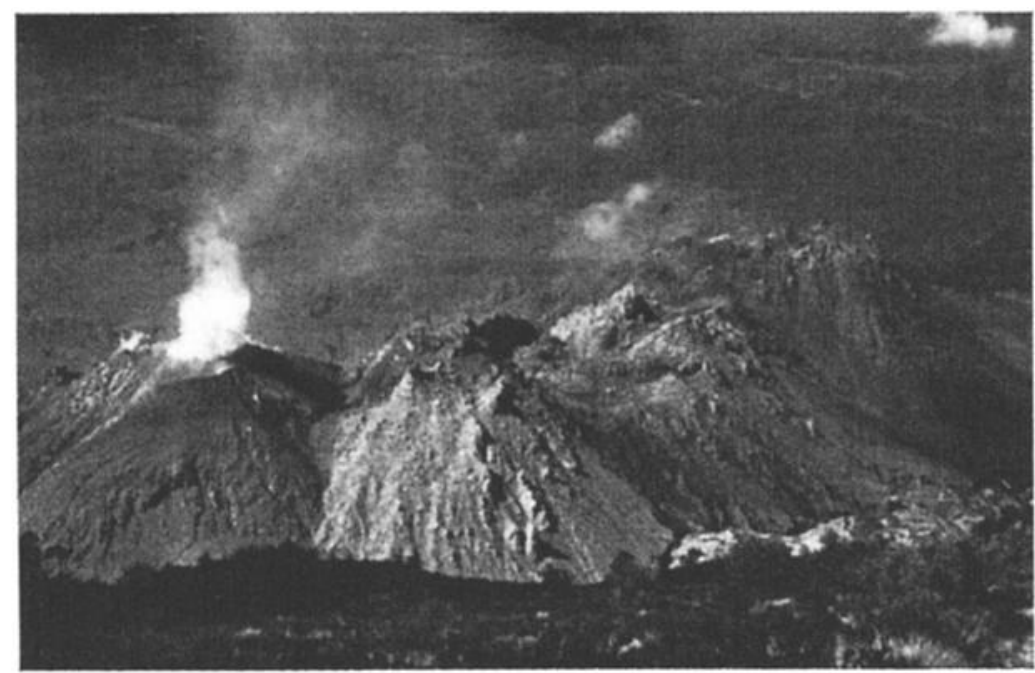

Figure 8. View to the southwest of the coalesced domes of the Santiaguito complex in February 1988. The active Caliente vent (at left) feeds a lava flow that extends several kilometers to the southwest. Field of view is approximately $2 \mathrm{~km}$ across. 


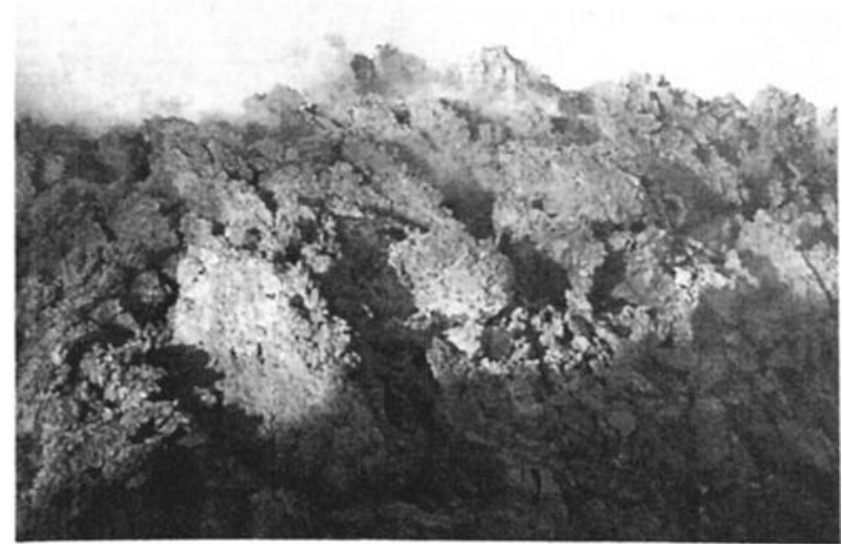

Figure 9. Close view of rough surface of the 1994 Merapi dome, showing fracture-bounded, scoriaceous blades roughly $3 \mathrm{~m}$ high. Photo taken in October 1995.

\subsection{Redoubt Volcano}

Between December 22, 1989, and June 15, 1990, 14 separate domes grew within the crater of Redoubt Volcano, Alaska. Compositional differences among the domes were barely distinguishable: silicic andesite $\left(\mathrm{SiO}_{2}=60 \%\right)$ with crystallinities of around $42 \%$. Most of the individual domes persisted for 3-9 days before being destroyed by gravitational collapse and associated pyroclastic activity. Miller [1994] divided the eruption into three stages with progressively lower effusion rates ranging from 2.2 to $0.18 \times 10^{6} \mathrm{~m}^{3} / \mathrm{d}\left(25.5\right.$ to $\left.2.1 \mathrm{~m}^{3} / \mathrm{s}\right)$; the overall lava production rate for the entire period (including repose intervals) was $0.5 \times 10^{5} \mathrm{~m}^{3} / \mathrm{d}\left(0.6 \mathrm{~m}^{3} / \mathrm{s}\right)$. Photographic observations were too limited to distinguish these three phases morphologically. The blocky surfaces of the observed domes exhibited small spines, crease structures, and other fractures, suggesting a classification between the spiny and lobate categories. Using the corresponding values of $\Psi_{B}$ with properties listed in Table 3 and the average lava production rate gives calculated yield strengths of 1.4 to $3.0 \times 10^{5} \mathrm{~Pa}$. Using the larger instantaneous effusion rates leads to a strength in the range $4.0 \times 10^{5}$ to $8.5 \times 10^{5} \mathrm{~Pa}$, which is our highest estimate among all the active domes considered.

\subsection{Montserrat}

The most deadly dome-forming eruption this century occurred in 1902 at Mont Pelée on the Caribbean island of Martinique. In 1995, andesite dome extrusion began on another Caribbean island, Montserrat, where collapse events have produced pyroclastic flows that traveled over $12 \mathrm{~km}$ to the sea, forcing the evacuation of over 1500 people from the town of Plymouth. The dome has structures and textures (R. Stewart, personal communication, 1996) placing it in the spiny to lo- bate category (thus $0.03<\Psi_{B}<0.3$ ). Repeated aerial photographs allowed calculation of an average growth rate of 2.5 $\mathrm{m}^{3} / \mathrm{s}$ (M. Dolan, personal communication, 1996), which when combined with a $T_{e}=1000^{\circ} \mathrm{C}$ and $T_{g}=720^{\circ} \mathrm{C}$ (and thus a $t_{S}=$ $90 \mathrm{~s}$ ) leads to a calculated yield strength of 2.4 to $5.0 \times 10^{5} \mathrm{~Pa}$. This high strength may help explain the large number and frequency of pyroclastic flows generated by the collapse of this dome.

\subsection{Summary}

For each of the eight domes described above, we have been able to use observations of morphologic type and average eruption rates $(Q)$, and knowledge of composition (and hence $T_{e}$ and $t_{S}$ ) to arrive at estimates of the interior yield strength $(\sigma)$. These calculations assume that the morphologic transitions defined in the laboratory using kaolin/PEG slurries are relevant to the emplacement of natural lava domes even though the latter involve much larger temporal and spatial scales, and poorly known rheologies. The similarity of the derived yield strengths to those independently measured in the laboratory [e.g., McBirney and Murase, 1984], and determined by earlier morphologic techniques [Hulme, 1974; Moore et al., 1978; Blake, 1990], reinforces the validity of our basic hypothesis of similitude between the natural domes and our laboratory domes having both an internal yield strength and a solidifying carapace.

\section{Dome Height and Carapace Strength}

For the eruptions of the Soufrière, Mount St. Helens, and Pinatubo lava domes discussed above, there exist detailed measurements of the volume of the entire dome and its dimensions. For the measured changes in volume of each dome the variation of height and radius can be compared with those predicted by the available models. The variation of height is the most diag nostic of the dynamical regimes [Griffiths and Fink, 1993] and we show in Figure 10 the measured height variations for these three domes. Griffiths and Fink [1993] found that a simple scaling for a dome in which there is a balance between gravity and the yield stress in the developing surface carapace (and whose volume $V$ is increasing with time as $V \sim Q t^{\alpha}$, where $Q$ and $\alpha$ are constants) gives a dome height that increases as

$$
h \sim\left(\sigma_{c} / g \rho\right)^{1 / 2}(K t)^{1 / 4}
$$

where $\sigma_{c}$ is the effective yield strength of the carapace, $g$ is the gravitational acceleration, $\rho$ is the lava density, and $x$ is the thermal diffusivity of the lava. A fit of this simple power law to the height of each dome describes the data very well (with the exception of the final days of the Pinatubo dome, when vertical spines were observed to appear). In contrast, the isothermal Bingham model (which gives corresponding power law expo-

Table 3. Magma properties assumed in paleo-eruption rate calculations

\begin{tabular}{lcccc}
\hline Composition & $T_{\mathrm{e}}{ }^{\circ} \mathrm{C}$ & $T_{\mathrm{g}}{ }^{\circ} \mathrm{C}$ & $t_{\mathrm{s}}, \mathrm{s}$ & $\sigma, 10^{5} \mathrm{~Pa}$ \\
\hline Rhyolite & 820 & 670 & 32 & 3.0 \\
Rhyodacite & 885 & 685 & 50 & 2.5 \\
Dacite & 950 & 700 & 65 & 2.0 \\
Silicic andesite & 975 & 710 & 78 & 1.5 \\
Andesite & 1000 & 720 & 90 & 1.0 \\
\hline
\end{tabular}




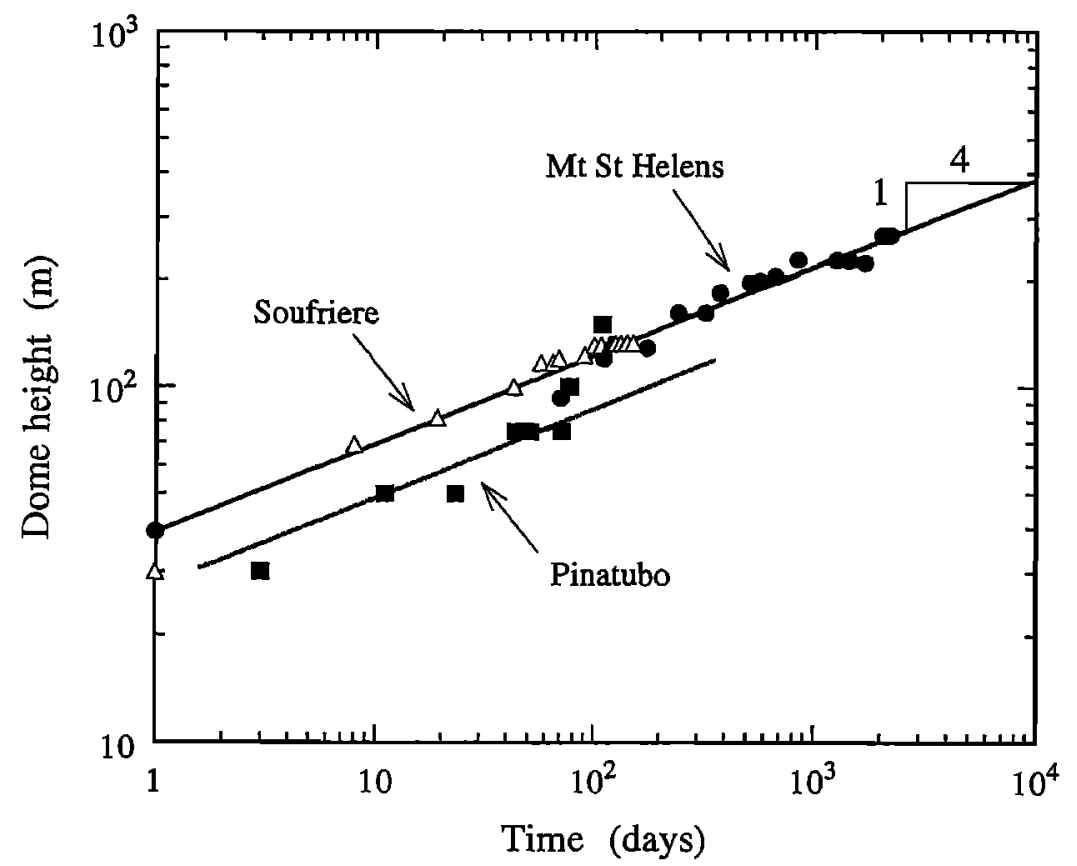

Figure 10. Dome height versus time for Soufrière, Mount St. Helens, and Pinatubo domes. The lines have slope $1 / 4$ and hence correspond to $h \sim t^{1 / 4}$. Data are from Shepherd et al. [1979], Swanson and Holcomb [1990], and Daag et al. [1996].

nents less than $1 / 5$, noting that the measurements for these domes show eruption rates declining with time) does not fit the data well and viscous models predict dome heights that decrease with time.

The agreement between the trends of the data and equation (2) is particularly significant because equation (2) does not involve the eruption rate or its time dependence (it might be increasing or declining) and because it shows that the behavior of the dome heights is the same as in our kaolin/wax experiments. Given this agreement, we proceed to evaluate the carapace strength by assuming the applicability of the strong carapace model. The fits shown in Figure 10 give $\sigma_{c}=1.3 \times 10^{8}$ $\mathrm{Pa}$ for both the Soufrière and Mount St. Helens domes and $\sigma_{c}=$ $1.0 \times 10^{8} \mathrm{~Pa}$ for the Pinatubo dome. These values are 1000 times greater than those we have found for the dome interiors, a difference that is consistent with the dominance of the carapace strength in determining the height and lateral spreading. Further evidence for the dominant role of carapace yield strength for the Soufrière and Mount St. Helens domes is provided by a comparison of the model and the variation of height with radius [Griffiths and Fink, 1993], although the first 20 days of the Soufrière eruption may be equally well described by the isothermal model.

\section{Eruption Rates of Prehistoric Domes and Flows}

Estimating likely eruption rates is an essential part of any hazards assessment involving emplacement of silicic magmas. However, such rates are poorly documented, particularly for areally extensive silicic lava flows such as the Chao dacite in Chile [de Silva et al., 1994], which have not been scientifically observed while active (Table 4 ). The above results suggest that eruption rates of prehistoric domes may be inferred from their morphology if the magma composition and timescale of solidification can be determined. Here we use this approach to calculate average eruption rates and durations for four such extrusions. We assume that all lavas of a given composition (rhyolite, rhyodacite, dacite, silicic andesite, or andesite) have the same $T_{g}, T_{e}$, and $\sigma$ and that the yield strength values are similar to those determined for the active flows described earlier (Table 3). The initial example has conditions that are most consistent with those in our experiments (minimal underlying slope, magma with significant yield strength, point-source vent). The three subsequent cases add complications (eruption from a fissure, flow down steep slopes, glassy magmas with questionable strengths) that allow us to evaluate how broadly applicable the model is. In each case these calculations provide new insights into the eruptive histories of silicic lavas.

\subsection{Obsidian Dome, California}

Obsidian Dome, just north of Long Valley Caldera in California, is one of only two Holocene rhyolite flows whose interior has been probed by research drilling. The flow contains lavas with two slightly different chemical compositions [Vogel et al., 1989], the more mafic of which makes up the base and outer margins and the more silicic of which forms the upper and more proximal portions. The morphology appears to correlate with these chemical differences (Figure 11). The more distal (and mafic) parts of the flow are covered by shortwavelength, continuous surface folds and a few prominent crease structures (indicating the platy regime; $0.9<\Psi_{B}<15$ ). The near-vent (more silicic) area is dominated by straightwalled fractures up to $20 \mathrm{~m}$ deep that separate spine-like blocks with oblique striations that appear to have been emplaced subvertically (cf. Fink, 1983). These structures suggest the spiny regime $\left(0.01<\Psi_{B}<0.12\right)$. Choosing for the mafic end-member an estimated $T_{e}=950^{\circ} \mathrm{C}$ [Carmichael et al., 
Table 4. Well-studied prehistoric domes and silicic flows

\begin{tabular}{|c|c|c|}
\hline Flow & Age, years BP & Selected References \\
\hline Mono Craters, Califormia & $600-10,000$ & $\begin{array}{l}\text { Loney [1969], Sieh and Bursik [1986], Bursik } \\
\text { and Sieh [1989], and Newman et al. [1988] }\end{array}$ \\
\hline $\begin{array}{l}\text { Inyo Domes, California (Obsidian, South } \\
\text { Glass Creek, South Deadman) }\end{array}$ & 600 & $\begin{array}{l}\text { Taylor et al. [1983], Eichelberger et al. } \\
\text { [1986], Manley and Fink [1987], Sampson } \\
\text { [1987], and Vogel et al. }[1987,1989]\end{array}$ \\
\hline $\begin{array}{l}\text { Medicine Lake Volcano, California } \\
\text { (Glass Mountain, Little Glass } \\
\text { Mountain, Crater Glass Flows, } \\
\text { Medicine Lake Dacite Flow) }\end{array}$ & 1000 & $\begin{array}{l}\text { Anderson [1933], Eichelberger [1978, 1980], } \\
\text { Heiken [1978], Fink [1983], Fink and } \\
\text { Manley [1987], Donnelly Nolan [1988], } \\
\text { and Fink et al. }[1992]\end{array}$ \\
\hline Central Andes & $<10,000$ & $\begin{array}{l}\text { Guest and Sanchez [1969], de Silva and } \\
\text { Francis [1991], and de Silva et al. [1994] }\end{array}$ \\
\hline Pantelleria, Italy & 10,000 & $\begin{array}{l}\text { Wright [1980], Mahood and Hildreth [1983], } \\
\quad \text { and Orsi et al. }[1991]\end{array}$ \\
\hline Valles Caldera, NM (Banco Bonito Flow) & $>10,000$ & Selfet al. $[1991]$ \\
\hline Southwest Idaho, USA & $14,000,000$ & $\begin{array}{l}\text { Bonnichsen and Kauffinan [1987], and Manley } \\
\text { [1996] }\end{array}$ \\
\hline
\end{tabular}

1974], $T_{g}=700^{\circ} \mathrm{C}$ [Westrich et al., 1988], and $\sigma=2 \times 10^{5} \mathrm{~Pa}$ gives $t_{S}=65 \mathrm{~s}$ and (from Figure 4) $Q=3.1-11 \mathrm{~m}^{3} / \mathrm{s}$. For the silicic end-member we assume $T_{e}=820^{\circ} \mathrm{C}, T_{\mathrm{g}}=670^{\circ} \mathrm{C}$ and $\sigma=$ $3 \times 10^{5} \mathrm{~Pa}$, from which we find $t_{S}=32 \mathrm{~s}$ and $Q t_{S}=0.6-3.4$ $\mathrm{m}^{3 / \mathrm{s}}$.

According to one interpretation [Blake and Fink, 1987; Vogel et al., 1989] the Obsidian Dome eruption tapped a dike in which the two end member magmas were density-stratified (mafic below silicic). The higher initial effusion rate selectively drew the less viscous mafic lava up through the overlying silicic cap [Blake, 1984]; as the eruption rate waned, the mafic/silicic interface was depressed and the more silicic magma came up the conduit. Our morphologic results can be used to place bounds on this transition: we infer that during the early mafic stage the rate declined from 11 to $3 \mathrm{~m}^{3} / \mathrm{s}$, while in the later more silicic stage the rate decreased further from around 3 to $0.6 \mathrm{~m}^{3} / \mathrm{s}$. Similar declines in eruption rate could be associated with many silicic flows with differing degrees of magma mixing. If we assign volumes of $0.13 \times 10^{9}$ and $0.04 \times$ $10^{9} \mathrm{~m}^{3}$ to the distal and near-vent portions of Obsidian Dome [Sampson, 1987], respectively, and average eruption rates of 7 and $2 \mathrm{~m}^{3} / \mathrm{s}$ for the mafic and silicic portions, we calculate that each phase of the eruption would have lasted between 200 and 230 days. Such estimates are useful to civil defense authorities trying to plan for future eruptions in the Mammoth Lakes area. Year-long dome eruptions, with their potential for pyroclastic flows generated by flow-front collapse, adjacent to one of the major ski resorts in the western United States, would cause severe economic impact. In contrast, eruptions characterized by flows emplaced at higher rates but over a shorter period (weeks to months) might have less effect on the local economy.

\subsection{Badlands Lava Flow, Idaho}

Among the most carefully studied voluminous silicic flows is the Badlands lava of SW Idaho [Manley, 1996], a $14 \mathrm{Ma}$, crystal-rich (30 vol \%), calc-alkalic rhyolite with a volume of about $15 \mathrm{~km}^{3}$. Although it is possible that the crystal content is too small to impart a yield strength to this rhyolite, we proceed cautiously and apply the Bingham model, keeping in mind that the earlier model for solidifying viscous flow may be a closer approximation to the Badlands flow. The upper carapace of this flow has been almost completely eroded, but its overall lobate morphology and the presence of internal ramp structures and shear zones suggest that it be placed within the lobate to platy category $\left(0.3<\Psi_{B}<3.0\right)$. Using the same rhyolitic values as for the silicic end-member of Obsidian Dome (Table 3), Figure 4 indicates that $Q t_{S}=400-2800 \mathrm{~m}^{3}$ and $Q=$ $13-88 \mathrm{~m}^{3} / \mathrm{s}$. This range overlaps with the overall effusion rates (30-237 $\left.\mathrm{m}^{3} / \mathrm{s}\right)$ calculated by Manley [1996] using a numerical cooling model and the empirical method of Kilburn and Lopes [1991] for emplacement of a flow field. These estimates suggest that emplacement of the Badlands lava would have taken between 7 and 47 years. Although these rates are comparable to some of the highest rates recorded for active domes (e.g., 40 $\mathrm{m}^{3} / \mathrm{s}$ for the June 1981 Mount St. Helens lobe; $22 \mathrm{~m}^{3} / \mathrm{s}$ for the Lamington andesite dome erupted in Papua New Guinea in 1951 [Swanson et al., 1987]), the volumes are much greater than any recorded effusive silicic eruptions and imply a large magma reservoir that remained in an eruptible condition for years to decades. The $7-14 \mathrm{~km}$ long dike that fed the flow also would have remained open for a much longer period than it would for mafic fissure eruptions, which quickly localize to one or two point-source vents. The ultimate heat source for this extensive magmatic episode was most likely the Yellowstone hot spot.

\subsection{Chao Dacite Flow, Chile}

The Chao dacite flow in Chile is one of the largest silicic extrusions in the world [Guest and Sanchez, 1969; de Silva et al., 1994]. Its surface is dominated by very large transverse ridges cut by smaller longitudinal fractures, which would normally place it within the platy regime $\left(0.9<\Psi_{B}<15\right)$. However, because the flow advanced down a slope of up to $20^{\circ}$, the morphology probably corresponds to a smaller effiusion rate, and hence a smaller $\Psi_{B}$ value (here we assume that $0.3<\Psi_{B}<3.0$ ). Using $T_{e}=840^{\circ} \mathrm{C}$ [de Silva et al., 1994] for this crystal-rich (43-53 vol \%) lava and $t_{S}=22 \mathrm{~s}$, along with a yield strength of $2 \times 10^{5} \mathrm{~Pa}$ gives $Q t_{\mathrm{S}}=100-700 \mathrm{~m}^{3}$ and $Q=$ 


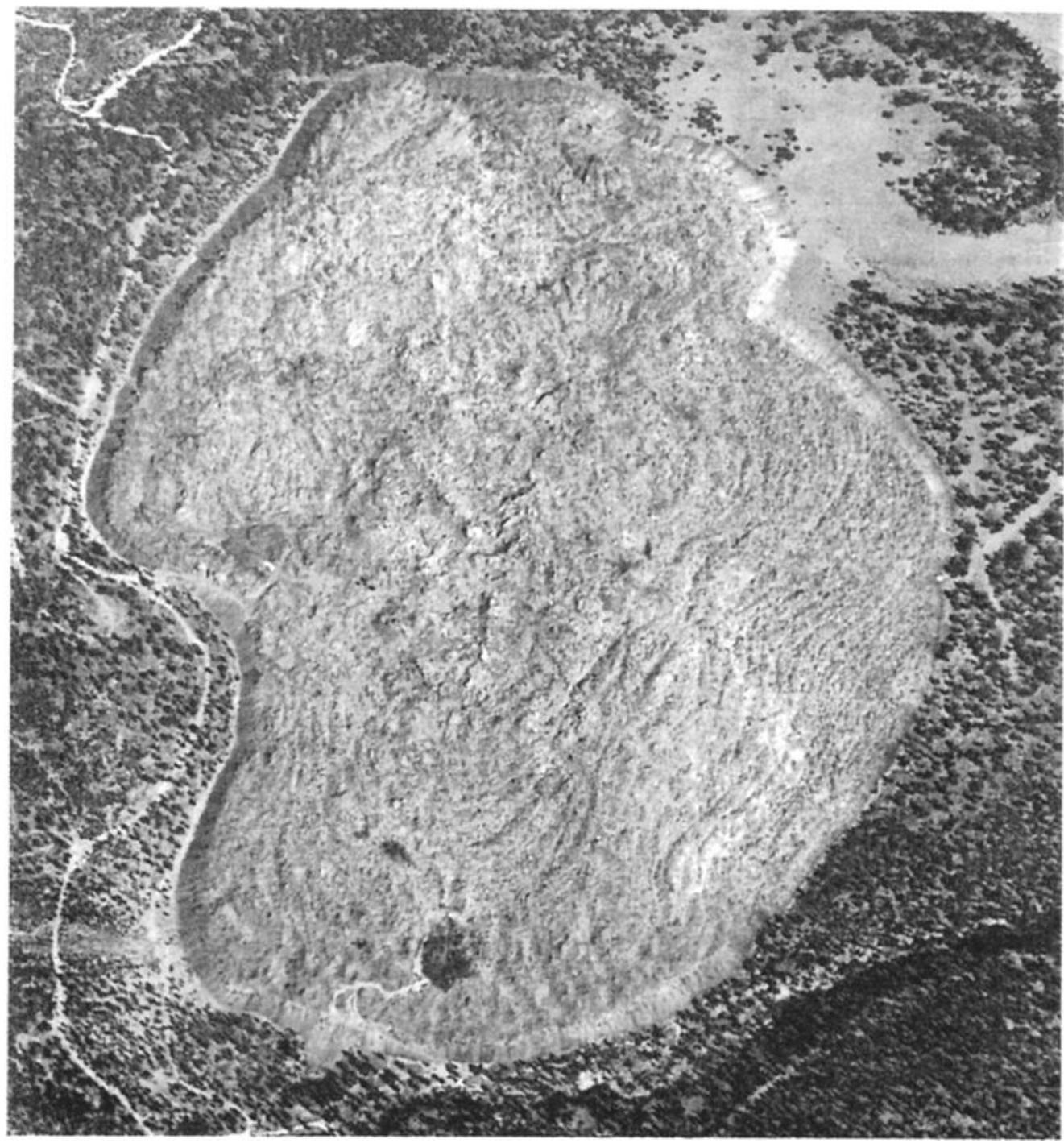

Figure 11. Aerial photograph of Obsidian Dome, eastern California (north at top). Flow is approximately $1 \mathrm{~km}$ across. Note well-developed surface folds on eastern portion, dark crease structures near southern margin, and large spines near center marking near-vent area composed of more silicic lava.

$4.5-32 \mathrm{~m}^{3} / \mathrm{s}$. This range is somewhat greater than that $(1.4$ $4.9 \mathrm{~m}^{3} / \mathrm{s}$ ) calculated independently by Manley [1996], using the method of Kilburn and Lopes [1991] with de Silva et al.'s [1994] data corrected to take into account the dry rock equivalent volume of $26 \mathrm{~km}^{3}$. If we use $t_{S}=65 \mathrm{~s}$ from Figure 3 with the $T_{e}$ assumed earlier for dacite $\left(950^{\circ} \mathrm{C}\right)$, rather than the lower eruption temperature published by de Silva et al. [1994], we would arrive at a range of eruption rates more consistent with Manley's: $Q=1.5-10 \mathrm{~m}^{3} / \mathrm{s}$. Judging from these numbers, we estimate that such an eruption would continue for between 9 and 56 years, similar to the calculated duration of the Badlands lava flow and in agreement with a long-duration eruption inferred by de Silva et al. [1994].

\subsection{South Sister Domes, Oregon}

South Sister Volcano in Oregon has a linear chain of about 16 rhyodacitic domes that have been interpreted as resulting from the emplacement of a segmented silicic dike [Scott, 1987; Fink and Manley, 1987]. In general, the largest of these extrusions are found highest on the volcano, with their morphologies varying slightly with size. All but the largest dome are composed of uniform, relatively smooth, glassy lava, with circular to ovoid outlines and central crease structures that parallel the north-south alignment of the chain, placing them in the spiny category (Figure 12a). The largest extrusion (the Newberry Flow) has spines and uniform textures near its vent and well-developed surface folds and more variable vesicularities in its distal portions (Figure 12b). Most of the flow can be characterized as platy. However, as the Newberry Flow traverses a slope of up to $25^{\circ}$, it probably resulted from an eruption rate (and range of $\Psi_{B}$ values) lower than those implied by its morphology alone.

Choosing eruption parameters for rhyodacite (Table 3) and assuming $0.01<\Psi_{B}<0.12$ for the smaller domes and $0.9<\Psi_{B}$ $<15$ for the Newberry Flow leads to estimates of $0.4<Q<6.4$ $\mathrm{m}^{3} / \mathrm{s}$ for the smaller domes and $0.4<Q<24 \mathrm{~m}^{3} / \mathrm{s}$ for the Newberry Flow. The eruption rates for individual domes, while within this range, may have been quite different from each other owing to variations in the width of the feeding dike, as flow rates through a slit scale as the third power of the width. A wider dike might be expected near the volcano summit where magma pressure may have been highest. Taking a nomi- 


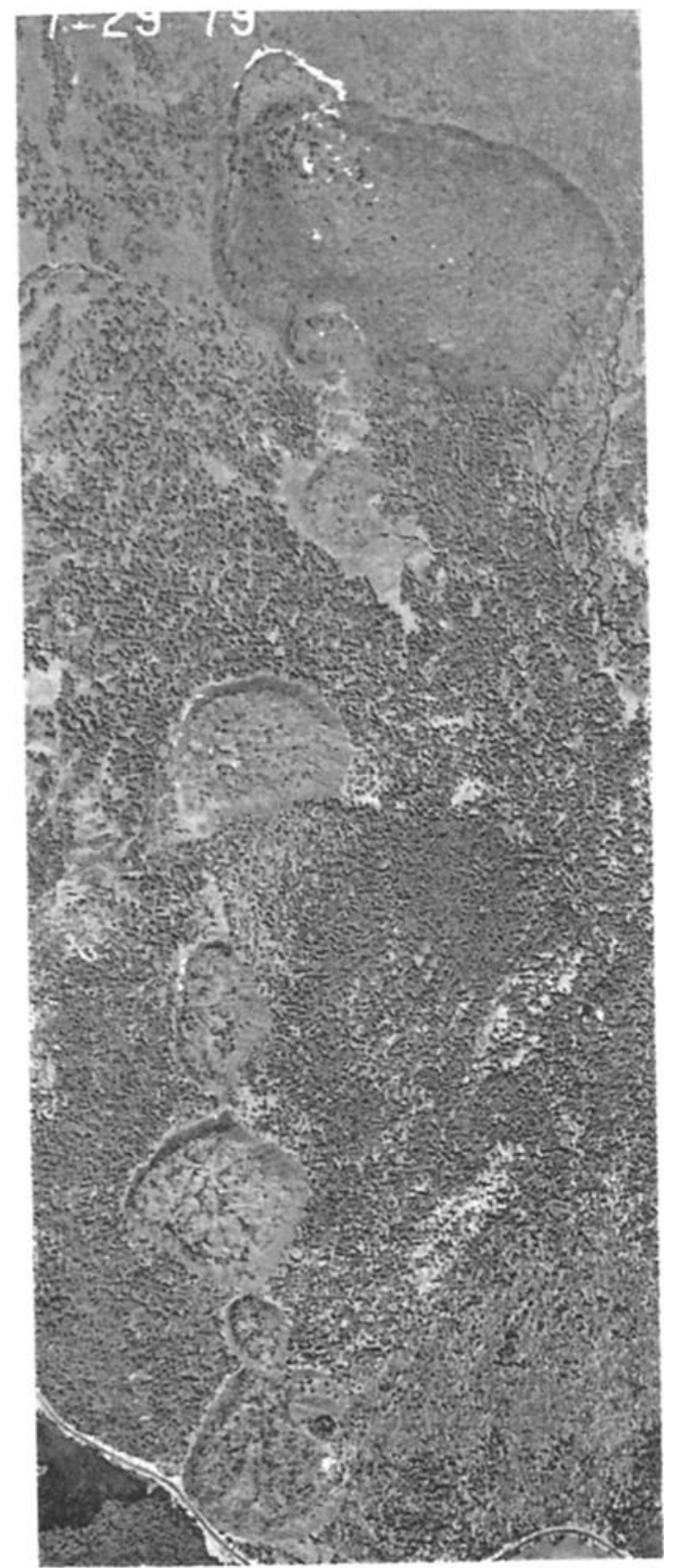

Figure 12a. Devil's Hill Domes, South Sister Volcano, Oregon, showing 15 smaller domes at south end of chain. Field of view is approximately $3.5 \mathrm{~km}$ north to south (photo from U. S. Forest Service).

nal volume of $0.03 \times 10^{9} \mathrm{~m}^{3}$ and average eruption rate of 3.2 $\mathrm{m}^{3} / \mathrm{s}$ for the smaller Devil's Hill domes and values of $0.10 \mathrm{x}$ $10^{9} \mathrm{~m}^{3}$ and $12 \mathrm{~m}^{3} / \mathrm{s}$ for the Newberry Flow, we calculate eruption durations of 108 days for the smaller domes and 96 days for the Newberry Flow. This general consistency suggests that many concurrently active vents spread along the entire silicic dike remained active for a period of 2-3 months, rather than localizing over a few hours or days to one or two vents, as commonly occurs for mafic fissure eruptions.

\section{Carapace Strength and Explosive Decompression of Domes}

One of the main goals of dome-emplacement studies is to find ways to predict which flows are most likely to undergo explosive decompression during front collapse. Of the eight active domes described earlier, five (Unzen, Santiaguito, Merapi, Redoubt, Montserrat) had significant endogenic pyroclastic phenomena associated with their growth, one (Mount St. Helens) had only isolated pyroclastic activity, and two (Soufrière, Pinatubo) had none reported. At least four other modern domes have collapsed to generate major pyroclastic flows: Mount Lamington (Papua New Guinea) in 1951 [Taylor, 1958], Mont Pelée (Martinique) in 1902 [Lacroix, 1904] and 1933 [Perret, 1937], and Mount St. Augustine (Alaska) in 1986 [Swanson and Kienle, 1988]. To first order, the most important factor influencing whether or not these domes have experienced explosive processes appears to be underlying topography. The three most quiescent domes (Soufrière, St. Helens, Pinatubo) were all emplaced on approximately flat surfaces, whereas the others all formed adjacent to steep slopes.

The relatively small number of well-documented examples precludes establishment of good statistical correlations between the explosive potential of domes and most other variables. For instance, all of the domes with violent collapse events listed above are crystal-rich dacites or andesites, and no active basalt or rhyolite domes have been scientifically observed, so that neither crystallinity nor chemical composition can be independently evaluated. Examination of prehistoric domes can provide some additional constraints: several young glassy rhyolites emplaced on gentle slopes (e.g., Obsidian Dome and Panum Crater in eastern California) have contemporaneous block and ash flow deposits around their margins, implying at least some pyroclastic flow generation. Other rhyolites (e.g., Little Glass Mountain at Medicine Lake Volcano; Big Obsidian Flow at Newberry Caldera) are pockmarked with large explosion craters, although these endogenic features appear to form only when volatiles become highly concentrated within a flow.

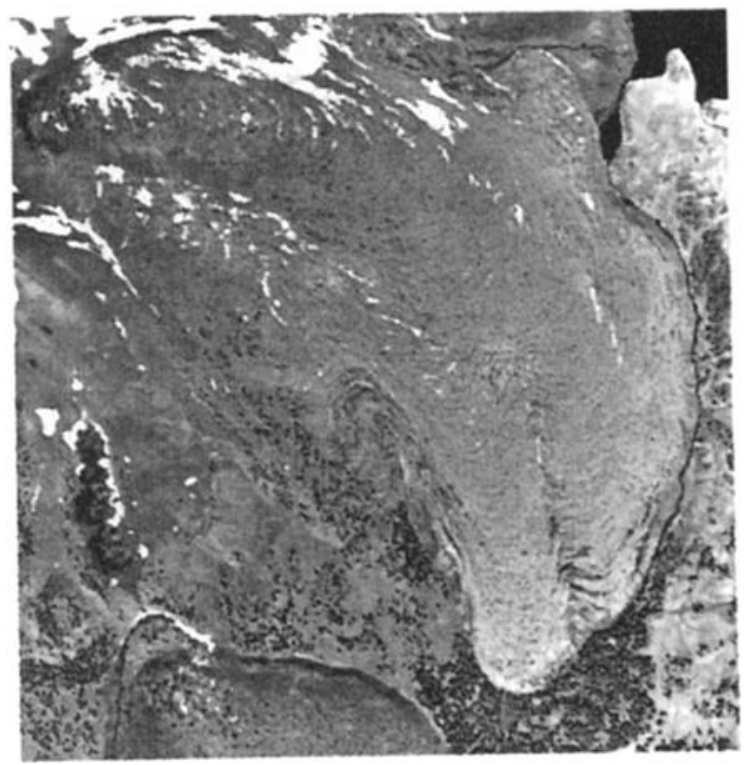

Figure 12b. Newberry Flow and four other small domes at north end of chain of Devil's Hill Domes, South Sister Volcano, Oregon. Field of view is approximately $2 \mathrm{~km}$ north to south (photo from U.S. Forest Service). 
If one accepts that underlying slope is a major factor influencing the likelihood of dome collapse, the next question is whether morphology can provide any indications of how violent the collapse-induced pyroclastic activity will be. Nearly all of the cited domes that gave rise to laterally extensive pyroclastic flows and surges could be classified between spiny and lobate (e.g., Unzen, Santiaguito). Those domes issuing more limited block and ash flows are either lobate (e.g., Mount St. Helens) or platy (e.g., Panum Crater; outer portions of Obsidian Dome). The two nonexplosive cases (Soufrière and $\mathrm{Pi}$ natubo) were lobate and platy/axisymmetric, respectively. These examples suggest that there may be some correlation between the intensity of explosive behavior and dome morphology $\left(\Psi_{B}\right)$, although one cannot clearly isolate the role of slope. In the following, we explore the implications of this possible relationship.

A knowledge of the carapace strength, along with its composition, thickness, and underlying slope, may allow us to estimate how much pressure can build up within a dome's interior [Fink and Kieffer, 1993]. Crudely, we might estimate one limiting value for the maximum volatile pressure $\Delta P$ that can be supported by the strong carapace using the simple force balance

$$
\Delta P L^{2} \leq \sigma_{c} \delta L
$$

where $L$ is the scale of the axisymmetric dome or of an individual lobe and $\delta$ is the carapace thickness. This criterion assumes that the plastic strength $\sigma_{c}$ of the carapace (which we have estimated from the growth of several domes) is the control on volatile pressure. Another possible limit to the pressure is given by a criterion for brittle failure. However, if we view the carapace as a complex and highly deformed layer, rather than as a simple unbroken solid layer, then the containment of volatile pressure may rely primarily on plastic deformation. The balance in equation (3) implies a maximum volatile pressure $\Delta P$ $\sigma_{c} \delta / L$. Thus thicker carapaces can support greater pressures.

In our experiments we find that the solid crust is approximately $1 \mathrm{~cm}$ thick on a lobate dome $10 \mathrm{~cm}$ in radius, a few millimeters thick on a platy dome, and no thicker than $1 \mathrm{~mm}$ on an axisymmetric dome. The crusts on lobate and platy domes would support pressures up to $1 / 100$ or $1 / 10$ of the crust yield strength. Carapace thicknesses (relative to flow dimensions) on lava domes further depend on crystallization rates and latent heat release. In any case, the thickness is poorly defined in the context of rheologic differences. However, if approximate experimental crust thicknesses (relative to dome dimensions) in each morphological regime carry over to lava domes of the same type, the carapace strengths estimated above imply that volatile pressures will range from less than $10^{6} \mathrm{~Pa}$ for axisymmetric domes to the order of $10^{7} \mathrm{~Pa}$ for lobate domes. Small lobes on a dome with equally thick carapaces may support slightly greater pressures. Spiny domes have even thicker solid crusts and so might support still greater pressures.

These rough calculations suggest a range of pressures that could be contained within domes of a given morphology and texture. We might further speculate that collapse of those domes with the highest internal pressures would lead to pyroclastic phenomena with the finest-scale fragmentation, highest velocities, and greatest dispersion [Fink and Kieffer, 1993]. If all other factors were equal, we might then expect collapse of platy domes to generate block and ash flows, whereas lobate or spiny domes would produce fully inflated pyroclastic flows and surges.

An alternative view of dome collapse (C.R. Manley, personal communication, 1997) suggests that endogenic pyroclastic flows originate from fragmentation of the solidified carapace, rather than from the release of gas pressure built up in the liquid magma beneath this crust. By allowing the thickness of the cooled surface layer to be calculated, our results permit the volume of potential pyroclastic material in a growing dome to be estimated. The thicker crusts of spiny and lobate domes would account for their greater tendency to generate violent pyroclastic flows and surges.

\section{Composition of Venusian "Pancake Domes"}

The enigmatic Venusian "pancake domes" have been interpreted as having compositions ranging from basalt to rhyolite, sometimes by the same authors in different papers [e.g., Fink and Bridges, 1995; Bridges, 1997]. We have previously proposed [Griffiths and Fink, 1992; Gregg and Fink, 1996] using the results of laboratory analog experiments with solidifying viscous extrusions to derive a relationship between magma viscosity and eruption rate that might let us use the morphology of "pancakes" to specify their compositions. If the pancake domes are considered to be individual large "pillows" (comparable to terrestrial submarine basalt pillows or endogenous lava domes), then any selected viscosity will be associated with a limited range of eruption rates. Based on terrestrial eruption conditions, the only pancake composition with reasonable effusion rates is andesitic.

Here we suggest two alternative hypotheses. The first is an expansion of our earlier argument that the magma lacked significant yield strength as it emerged from the vents, but that each pancake is better considered to be near the opposite or pillow end of the spectrum of morphologies seen in the viscous experiments, i.e., in the "levee" regime, where flows tend to remain symmetric for a time [e.g., Fink and Griffiths, 1990]. Our second and preferred hypothesis is that the erupted magma spread in a manner controlled by a strong carapace but with an eruption style influenced by an interior yield strength.

According to the first hypothesis, an application of the viscous scaling under Venusian conditions can be taken directly from Griffiths and Fink [1992, equation (9) and Figure 7]. For the levee regime, and assuming that cooling must produce sufficient crust to stop spreading at the currently observed radii of the pancake domes, we set $20<\Psi<50$, where $\Psi$ is the parameter in the viscous scaling which corresponds to $\Psi_{B}$. For a viscosity of $10^{3} \mathrm{~Pa}$ this implies eruption rates in the range 9 $\times 10^{-7}<Q<3 \times 10^{-5} \mathrm{~m}^{3} \mathrm{~s}^{-1}$; for $\eta=10^{5} \mathrm{~Pa}$ s it implies $0.9<Q$ $<30 \mathrm{~m}^{3} \mathrm{~s}^{-1}$; for $\eta=10^{7} \mathrm{~Pa} \mathrm{~s}, 9 \times 10^{5}<Q<3 \times 10^{7} \mathrm{~m}^{3} \mathrm{~s}^{-1}$, and for $\eta=10^{9} \mathrm{~Pa} \mathrm{~s}$, it gives $9 \times 10^{11}<Q<3 \times 10^{13} \mathrm{~m}^{3} \mathrm{~s}^{-1}$. Of these combinations, the one that seems most reasonable when compared with terrestrial examples is the intermediate viscosity case (i.e., $\eta=10^{5} \mathrm{~Pa} \mathrm{~s}$ ), which corresponds to crystal-rich basaltic andesite or crystal-poor andesite compositions. More viscous (i.e., more silicic) magmas imply unrealistic eruption rates and, in any case, would most likely have significant yield strengths, precluding the relevance of the viscous scaling. 
In the second hypothesis we apply the Bingham scaling developed in this paper. The Venusian domes, with their remarkably circular outlines and relatively uniform surface texture, appear to lie within the axisymmetric regime, indicating high eruption rates relative to cooling rates $\left(15<\Psi_{B}<\right.$ 100 , where we include the upper limit only as a rough guide and because McKenzie et al. [1992] present evidence that the measured height profiles are inconsistent with a simple isothermal model). In placing limits on $Q$ for different assumed compositions we again take account of the slightly faster cooling of the lava under the hot but dense Venusian atmosphere [Head and Wilson, 1986; Griffiths and Fink, 1992]. If we assume a yield strength $\sigma=3 \times 10^{5} \mathrm{~Pa}$ and other properties appropriate to rhyolite on Earth (Table 3), then $15<\Psi_{B}<100$ implies $8 \times 10^{2}<\mathrm{Q}<6 \times 10^{3} \mathrm{~m}^{3} \mathrm{~s}^{-1}$. For different compositions, the same range of $\Psi_{B}$ translates to $1.2 \times 10^{2}<\mathrm{Q}<8 \times 10^{2}$ $\mathrm{m}^{3} \mathrm{~s}^{-1}$ for dacite, $10<Q<67 \mathrm{~m}^{3} \mathrm{~s}^{-1}$ for andesite, and $0.8<Q$ $<6 \mathrm{~m}^{3} \mathrm{~s}^{-1}$ for basalt. Comparing these ranges with those for terrestrial eruptions of various compositions, and assuming that similar magmas have similar eruption rates on Earth and Venus, suggests that the pancakes are most likely to be basalt to basaltic andesite. Thus the viscous and Bingham models lead to nearly the same conclusion on the composition for the pancakes.

We also note that the height profile of the axisymmetric and platy laboratory domes (Figure 2) is a low rounded shape not very different from the shape of the Venus pancakes [McKenzie et al., 1992]. Thus the pancake profiles do not by themselves rule out an eruption style controlled by an interior strength and a dome height profile controlled by a strong carapace near the flow front rather than by an interior viscosity. The symmetry, surface appearance, and inferred range of eruption rates for the Venusian pancake domes all appear to be consistent with their being composed of a basalt to basaltic andesite magma having a yield strength.

\section{Summary}

Through laboratory simulations and comparisons with photographic analysis and field studies, we have developed a fourfold classification system for lava domes and silicic lava flows that relates their morphology and surface texture to their rheology and cooling history. Spiny domes, which have the lowest extrusion rates, highest strengths, highest viscosities, and highest cooling rates, are steep-sided and subcircular, with prominent surface spines. Higher extrusion rates, lower strengths, lower viscosities, and/or lower cooling rates lead to domes and flows we refer to as lobate, platy, or axisymmetric. This progression corresponds to flows with increasingly regular flow outlines, fewer and shorter lobes, flatter cross sections, and more varied surface textures. The morphologic classification relates to the strength of the dome's carapace, which also influences how much pressure is able to build up in the flow interior. Thus explosive hazards associated with the collapse of flow fronts are likely to be most intense for spiny and lobate domes.

Laboratory simulations using slurries of kaolin powder mixed with polyethylene glycol wax allow us to quantify the transitions from one morphologic type to another, if it is assumed that the flows are characterized by a balance between gravity and crust yield strength and that a yield strength also plays a role in the dome interior. A single dimensionless num- ber, $\Psi_{B}$, containing gravity, density, strength, extrusion rate, eruption temperature, and glass transition temperature, can be associated with each of the four dome types. Using our classification scheme with measured eruption rates, we have estimated $\Psi_{B}$ from the morphology and use it to calculate the interior yield strengths for eight well-monitored domes. Comparison of these strengths with those measured for lavas in the laboratory provides a check on the consistency of the model. We can also combine the morphology of prehistoric flows with assumptions about strength, eruption temperature, and glass transition temperature to arrive at estimates for eruption rates. Comparing these estimated rates with those previously determined for recent extrusions using independent methods provides a second check on the relevance of the model. This approach may be useful in estimating the emplacement conditions of other prehistoric and extraterrestrial lava domes.

Acknowledgments. Research was supported by National Science Foundation grants OCE 93-16831 and EAR 96-14330 and NASA grant NAGW 529 from the Planetary Geology and Geophysics Program. Tony Beasley and Derek Corrigan assisted with development of the experimental apparatus. Thanks to Curt Manley for helpful discussions and to Bill Chadwick, Stephen Self, and Alexander McBimey for constructive reviews.

\section{References}

Anderson, C. A., Volcanic history of Glass Mountain, northern California, Am. J. Sci., 26, 485-506, 1933.

Anderson, S. W., and I. H. Fink, The development and distribution of surface textures at the Mount St. Helens dome, in Lava Flows and Domes, IAVCEI Proc. Volcan., vol. 2, edited by J. H. Fink, pp. 2546, Springer-Verlag, New York, 1990.

Anderson, S. W. and J. H. Fink, Crease structures: Indicators of emplacement rates and surface stress regimes of lava flows, Geol. Soc. Am. Bull. 104(5), 615-625, 1992.

Anderson, S. W., J. H. Fink, and W. I. Rose Jr., Mount St. Helens and Santiaguito lava domes: The effect of short term eruption rate on surface texture and degassing processes, J. Volcanol. Geotherm. Res., 69, 105-116, 1995.

Blake, S., Magma mixing and hybridization processes at the alkalic, silicic Torfajokull central volcano triggered by tholeitic Veidivotn fissuring, South Iceland, J. Volcanol. Geotherm. Res., 22, 1-31, 1984.

Blake, S., Viscoplastic models of lava domes, in Lava Flows and Domes, IAVCEI Proc. Volcan., vol. 2, edited by J. H. Fink, pp. 88-126, Springer-Verlag, New York, 1990.

Blake, S., and J. H. Fink, The dynamics of magma withdrawal from a stratified dyke. Earth Planet. Sci. Lett., 85, 516-524, 1987.

Bogoyavlenskaya, G. E, and I. T. Kirsanov, Twenty five years of Bezymianny volcano activity (in Russian), Vulkanol. Seysmol., 1981(2), 3-13, 1981.

Bogoyavlenskaya, G. E., and I. T. Kirsanov, Thirty year investigation of the growth of the intracrateral dome at Bezymianny volcano: Peculiarities of its development and the character of volcanic hazard, in IUGG General Assembly 19, vol. 2, p. 417, Int. Union of Geod. and Geophys., Vancouver, Canada, 1987.

Bonnichsen, B., and D. F. Kauffman, Physical features of rhyolite lava flows in the Snake River Plain volcanic province, southwestern Idaho, Spec. Paper. Geol. Soc. Am., 212, 119-145, 1987.

Braitseva, O. A., I. V. Melekestsev, G. E. Bogoyavlenskaya, and A. P. Maksimov, Bezymianny: Eruptive history and dynamics, Volcanol. Seismol., 12, 165-194, 1991.

Bridges, N. T., Ambient effects on basalt and rhyolite lavas under venusian, subaerial, and subaqueous conditions, J. Geophys. Res., 102(E4), 9243-9255, 1997.

Bursik, M., and K. E. Sieh, Range front faulting and volcanism in the Mono Basin, eastern Califomia, J. Geophys. Res., 94, 15,587$15,609,1989$.

Calvache, M. L. and S. N. Williams, Emplacement and petrological evolution of the andesitic dome of Galeras Volcano, 1990-1992. J. Volcanol. Geotherm. Res., 77, 57-70, 1997. 
Carmichael, I., F. Turner, and J. Verhoogen, Igneous Petrology, McGraw-Hill, New York, 1974.

Chadwick, W. W. Jr., R. J. Archuleta, and D. A. Swanson, The mechanics of ground deformation precursory to dome-building extrusions at Mount St. Helens 1981-1982, J. Geophys. Res., 93, 4351$4366,1988$.

Daag, A. S., M. T. Dolan, E. Laguerta, G. P. Meeker, C. G. Newhall, J. S. Pallister, and R. Solidum, Growth of a post-climactic lava dome at Pinatubo Volcano, July-October 1992, in Fire and mud: Eruptions and lahars of Mount Pinatubo, Philippines, edited by C. Newhall, and R. Punongbayan, pp. 647-664, Univ. of Wash. Press, Seattle, 1996.

de Silva, S. L., and P. W. Francis, Volcanoes of the Central Andes, 216 pp., Springer-Verlag, New York, 1991.

de Silva, S. L., S. Self, P. W. Francis, R. E. Drake, and R. C. Ramirez, Effusive silicic volcanism in the central Andes: The Chao dacite and other young lavas of the Altiplano-Puna volcanic complex, $J$. Geophys. Res., 99, 17,805-17,826, 1994.

Donnelly-Nolan, J. M., A magmatic model of Medicine Lake volcano, California, J. Geophys. Res., 93, 4412-4420, 1988.

Eichelberger, J. C., Andesitic volcanism and crustal evolution, Nature, 275, 21-27, 1978.

Eichelberger, J. C., Vesiculation of mafic magma during replenishment of silicic magma reservoirs, Nature, 288, 446-450, 1980.

Eichelberger, J. C., C. R. Carrigan, H. R. Westrich, and R. H. Price, Non-explosive silicic volcanism, Nature, 323, 598-602, 1986.

Fink, J. H., Surface folding and viscosity of rhyolite flows, Geology, 8, $250-254,1980$.

Fink, J. H., Structure and emplacement of a rhyolitic obsidian flow: Little Glass Mountain, Medicine Lake Highland, northern California, Geol. Soc. Am. Bull., 94, 362-380, 1983.

Fink, J. H., and N. T. Bridges, Effects of eruption history and cooling rate on lava dome growth. Bull. Volcanol., 57, 119-239, 1995.

Fink, J. H., and R. W. Griffiths, Radial spreading of viscous-gravity currents with solidifying crust. J. Fluid. Mech., 221, 485-510, 1990.

Fink, J. H., and R. W. Griffiths, A laboratory analog study of the morphology of lava flows extruded from point and line sources. $J$. Volcanol. Geotherm. Res., 54, 19-32, 1992.

Fink, J. H., and S. W. Kieffer, Estimate of pyroclastic flow velocities resulting from explosive decompression of lava domes, Nature, 363, 612-615, 1993.

Fink, J. H., and C. R. Manley, Origin of pumiceous and glassy textures in rhyolite flows and domes, Spec. Pap. Geol. Soc. Am., 212, 77-88, 1987.

Fink, J. H., S. W. Anderson, and C. R. Manley, Textural constraints on effusive silicic volcanism: Beyond the permeable foam model, $J$. Geophys. Res., 97, 9073-9083, 1992.

Fink, J. H., M. C. Malin, and S. W. Anderson, Intrusive and extrusive growth of the Mount St. Helens lava dome, Nature, 348, 435-437, 1990 .

Greeley, R. and M. B. Womer, Mare basin filling on the moon: Laboratory simulations, Proc. Lunar Planet. Sci. Conf., 12B, 651-663, 1981.

Gregg, T. K. P. and J. H. Fink, Quantification of submarine lava-flow morphology through analog experiments, Geology, 23, 73-76, 1995.

Gregg, T. K. P. and J. H. Fink, Quantification of extraterrestrial lava flow effusion rates through laboratory simulations, $J$. Geophys. Res., 101, 16,891-16,900, 1996.

Griffiths, R. W. and J. H. Fink, The surface morphology of lava flows under planetary environments: Predictions from analog experiments, J. Geophys. Res., 97, 19,739-19,748, 1992.

Griffiths, R. W. and J. H. Fink, Effects of surface cooling on the spreading of lava flows and domes, J. Fluid Mech., 252, 667-702, 1993.

Griffiths, R. W. and J. H. Fink, Solidifying Bingham extrusions: A model for the growth of silicic lava domes, J. Fluid Mech., 347, 13-36, 1997.

Guest, J. E., and J. Sanchez, A large dacitic lava flow in Northem Chile, Bull. Volcanol., 33, 778-790, 1969.

Hallworth, M. A., H. E. Huppert, and R. S. J. Sparks, A laboratory simulation of basaltic lava flows, Modern Geology, 11, 93-107, 1987.

Hammer, J. E., and K. V. Cashman, Magmatic processes revealed by textural and compositional trends in Merapi dome lavas, J. Volcanol. Geotherm. Res., (in press) 1998.
Head, J. W, and L. Wilson, Volcanic processes and landforms on Venus: Theory, predictions and observations, J. Geophys. Res., 91, 9407-9446, 1986.

Heiken, G., Plinian-type eruptions in the Medicine Lake Highland, California, and the nature of the underlying magma, J. Volcanol. Geotherm. Res., 4, 375-402, 1978.

Hodgson, G. W., An experimental investigation of simulated lava flows using carbowax materials, M.S. thesis, Air Force Inst. of Technol., Wright Patterson Air Force Base, Dayton, Ohio, 1969.

Hulme, G., The interpretation of lava flow morphology, Geophys. J. R. Astron. Soc., 39, 361-383, 1974.

Huppert, H. E., The propagation of two-dimensional and axisymmetric viscous gravity currents over a rigid horizontal surface, $J$. Fluid Mech., 121, 43-58, 1982.

Huppert, H. E., J. B. Shepherd, H. Sigurdsson, and R. S. J. Sparks, On lava dome growth, with application to the 1979 lava extrusion of the Soufrière of St. Vincent, J. Volcanol. Geotherm. Res., 14, 199$222,1982$.

Kilbum, C. R. J. and R. M. Lopes, General pattems of flow field growth: Aa and blocky lavas, J. Geophys. Res., 96, 19,721-19,732, 1991.

Lacroix, A., La Montagne Pelée et ses Éruptions, 664 pp., Masson, Paris, 1904.

Loney, R. A., Flow structure and composition of the Southern Coulee, Mono Craters, Califomia--A pumiceous rhyolite flow, Mem. Geol. Soc. Am.., 116, 415-440, 1969.

Manley, C. R., Physical volcanology of a voluminous rhyolite lava flow: The Badlands lava, Owyhee Plateau, southwestem Idaho, J. Volcanol. Geotherm. Res., 71, 129-153, 1996.

Manley, C.R., and J. H. Fink, Internal textures of rhyolite flows as revealed by research drilling, Geology, 15, 549-552, 1987.

Masao, M., Showa-Shinzan diary: complete records of observation of the process of the birth of Showa-Shinzan, paper presented at 50th Anniversary Meeting, Showa-Shinzan eruption, (sponsor, Exec. Committee, Int. Workshop on Volcanoes) Hokkaido, Japan, 1995.

McBirney, A. R., and T. Murase, Rheological properties of magmas, Ann. Rev. Earth Planet. Sci., 12, 337-357, 1984.

McKenzie, D., P. G. Ford, F. Liu, and G. H. Pettingill, Pancake-like domes on Venus, J. Geophys. Res., 97, 15,967-15,976, 1992.

Miller, T. P., Dome growth and destruction during the 1989-1990 eruption of Redoubt Volcano, J. Volcanol. Geotherm. Res., 62, 197 212, 1994.

Moore, H. J., D. W. G. Arthur, and G. G. Schaber, Yield strengths of flows on the Earth, Mars, and Moon, Proc. Lunar Planet. Sci. Conf., 9, 3351-3378, 1978.

Murase, T., A. R. McBimey, and W. G. Melson, Viscosity of the dome of Mount St. Helens, J. Volcanol. Geotherm. Res., 24, 193-204, 1985.

Nakada, S., and T. Fujii, Preliminary report on the activity at Unzen volcano (Japan), November 1990-November 1991: Dacite lava domes and pyroclastic flows, J. Volcanol. Geotherm. Res., 54, 319-333, 1993.

Nakada, S., Y. Miyake, H. Sato, O. Oshima, and A. Fujinawa, Endogenous growth of a dacite dome at Unzen volcano (Japan), 19931994, Geology, 23, 157-160, 1995.

Newhall, C., Research at Decade Volcanos aimed at disaster prevention, EOS Trans. AGU, 75, 340-350, 1994.

Newman, S., S. Epstein, and E. Stolper, Water, carbon dioxide, and hydrogen isotopes in glasses from the ca. 1340 A.D. eruption of the Mono Craters, Califomia: Constraints on degassing phenomena and initial volatile content, $J$. Volcanol. Geotherm. Res., 35, 75-96, 1988.

Orsi, G., L. Ruvo, and C. Scarpati, The recent explosive volcanism at Pantellaria, Geol. Rundsch., 80, 187-200, 1991.

Park, S. O., and J. D. Iversen, Dynamics of lava flow: Thickness growth characteristics of steady two-dimensional flow, J. Volcanol. Geotherm. Res., 11, 641-644, 1984.

Perret, F. A., The eruption of Mt. Pelée 1929-1932, Carnegie Inst. Washington Publ., 458, 126 pp., 1937.

Power, J. A., J. C. Lahr, and J. N. Davies, Seismic evolution of the 19891990 eruption sequence of Redoubt Volcano, Alaska, J. Volcanol. Geotherm. Res., 62, 69-94, 1994.

Ratdomopurbo, A., Etude sismologique du volcan Merapi et formation du dome de 1994, Ph.D. Dissertation, Univ. de Grenoble, Grenoble, France, 1995.

Rose, W. I., Jr., Santiaguito volcanic dome, Guatemala, Geol. Soc. Am. Bull., 83, 1413-1434, 1972. 
Rose, W. I., Jr., Pattern and mechanism of volcanic activity at the Santiaguito volcanic dome, Guatemala, Bull. Volcanol., 37, 73-94, 1973.

Rose, W. I., Jr., Volcanic activity at Santiaguito volcano, 1976-1984, Spec. Pap. Geol. Soc. Am., 212, 17-27, 1987.

Rose, W. I., Jr., T. Pearson, and S. Bonis, Nuée ardente eruption from the foot of a dacite lava flow, Santiaguito volcano, Guatemala, Bull Volcanol., 40, 1-16, 1976-1977.

Sampson, D. E., Textural heterogeneities and vent area structures in the 600-year-old lavas of the Inyo volcanic chain, eastern California, Spec. Pap. Geol. Soc. Am., 212, 89-101, 1987.

Sanchez B., W. I. Rose Jr., and F. M. Conway, Santa María, Guatemala: A decade volcano, EOS Trans. AGU, 73, 521-522, 1992.

Scott, W. E., Holocene rhyodacite eruptions on the flanks of South Sister volcano, Oregon, Spec. Pap. Geol. Soc. Am., 212, 35-53, 1987.

Self, S., J. A. Wolff, T. L. Spell, C. E. Skuba, and M. M. Morrissey, Revisions to the stratigraphy and volcanology of the post- $0.5 \mathrm{Ma}$ units and the volcanic section of VC-1 core hole, Valles Caldera, New Mexico, J. Geophys. Res., 96, 4107-4116, 1991.

Shepherd J. B., and H. Sigurdsson, Mechanism of the 1979 explosive eruption of the Soufrière volcano, St. Vincent, J. Volcanol. Geotherm. Res., 13, 119-130, 1982.

Shepherd, J.B., W. P. Aspinall, K. C. Rowley, J. A. Pereira, H. Sigurdsson, R. S. Fiske, and J. F. Tomblin, The eruption of Soufrière Volcano, St. Vincent, April-June, 1979, Nature, 282, 24-28, 1979.

Sieh, K., and M. I. Bursik, Most recent eruption of the Mono Craters, eastern central California, J. Geophys. Res., 91, 12,539-12,571, 1986.

Sukyhar, R., Learning from the 22 November 1994 Merapi eruption, paper presented at Merapi Decade Volcano Workshop, (sponsor, Volcanological Survey of Indonesia) Yogyakarta, Indonesia, 1995.

Swanson, D. A., and R. T. Holcomb, Regularities in growth of the Mount St. Helens dacite dome, 1980-1986, in Lava Flows and Domes, IAVCEI Proc. Volcanol, vol. 2, edited by J. H. Fink, pp. 3-24, Springer-Verlag, New York, 1990.

Swanson, D. A., D. Dzurisin, R. T. Holcomb, E. Y. Iwatsubo, W. W. Chadwick Jr., T. J. Casadevall, J. W. Ewert, and C. C. Heliker, Growth of the lava dome at Mount St. Helens, Washington (USA), 1981-1983, Spec. Pap. Geol. Soc. Am., 212, 1-16, 1987.
Swanson, S. E., and J. Kienle, The 1986 eruption of Mount St. Augustine: Field test of a hazard evaluation, J. Geophys. Res., 93, 4500-4520, 1988.

Taylor, B. E., J. C. Eichelberger, and H. R. Westrich, Hydrogen isotopic evidence of rhyolitic magma degassing during shallow intrusion and emplacement, Nature, 306, 541-545, 1983.

Taylor, G. A. M., The 1951 eruption of Mount Lamington, Papua, Bull. Bur. Miner. Res. Austr., 38, 118 pp., 1958.

Vogel, T. A., L. W. Younker, and B. C. Schuraytz, Constraints on magma ascent, emplacement, and eruption: Geochemical and mineralogical data from drill core samples at Obsidian Dome, Inyo Chain, CA, Geology, 15, 405-408, 1987.

Vogel, T. A., J. C. Eichelberger, L. W. Younker, B. C. Schuraytz, J. P. Horkowitz, H. W. Stockman, and H. R. Westrich, Petrology and emplacement dynamics of intrusive and extrusive rhyolites of $\mathrm{Ob}$ sidian Dome, Inyo Craters volcanic chain, eastern California, $J$. Geophys. Res., 94, 17,937-17,956, 1989.

Westrich, H. R. H. W. Stockman, and J. C. Eichelberger, Degassing of thyolitic magma during ascent and emplacement, $J$. Geophys. Res., 93, 6503-6511, 1988.

Williams, H., The history and character of volcanic domes, Univ. Calif. Publ. Geol. Sci., 21, 41-146, 1932.

Wright, J. V., Stratigraphy and geology of the welded air-fall tuffs of Pantellaria, Italy, Geol. Rundsch., 69, 263-291, 1980.

Young, K. D., B. Voight, J. Marso, Subandriyo, Sajiman, Miswanto, Paijo, Suharno, and S. Bronto, Tilt monitoring, lava dome growth, and pyroclastic-flow generation at Merapi Volcano, Java, Indonesia (abstract), Geol. Soc. Am. Abstr. Programs, 26, 483, 1994.

J. H. Fink, Department of Geology, Box 871404, Arizona State University, Tempe, AZ 85287-1404. (e-mail: jon.fink@asu.edu)

R. W. Griffiths, Research School of Earth Sciences, Australian National University, Canberra 0200, ACT, Australia. (e-mail: ross.griffiths@anu.edu.au)

(Received April 15, 1997; revised August 22, 1997; accepted October 3, 1997.) 